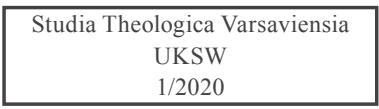

Pawel Bortkiewicz TChr

\title{
CZKOWIEK JAKO MISTERIUM OSOBY. WOKÓŁ PERSONALIZMU JANA PAWŁA II
}

W czasie pontyfikatu Jana Pawła II została opublikowana w Krakowie książka Karola Wojtyły, której tekst powstawał w roku 1949. To zapiski wygłoszonych w duszpasterstwie akademickim w Krakowie wykładów, zatytułowanych „Rozważania o istocie człowieka”.

Ten tekst mógł zadziwiać z kilku względów. Był bowiem kolejnym „odkrytym”, wcześniej nieznanym tekstem Karola Wojtyły. Jako tekst młodego człowieka i kapłana jest świadectwem dużej jasności i głębi myślenia młodego filozofa i duszpasterza. Wreszcie, pozostaje świadectwem wspomnianej wyżej, a tak charakterystycznej dla Karola Wojtyły metody myślenia i metody wykładu. Sam Autor stwierdza: „Wybierając człowieka jako temat naszych rozważań, musimy od razu bliżej określić, że można się zajmować tym tematem albo pod kątem losu człowieka, albo też pod kątem jego istoty. Wybieramy to drugie. Los bowiem człowieka w ogromnej mierze stanowi konsekwencję jego istoty"2.

Właśnie owo dążenie do zgłębienia istoty, przechodzenie „od fenomenu do fundamentu" (jak to określił później Jan Paweł II w encyklice „Fides et ratio”) stanowi swoisty klucz metodologiczny myśli wojtyliańskiej. Jest to zarazem propozycja, która została przedłożona

\footnotetext{
K. Wojtyła, Rozważania o istocie człowieka, Kraków 1999.
}

2 Ibidem, 18. 


\section{MAN AS A MYSTERY OF THE PERSON. AROUND THE PERSONALISM OF JOHN PAUL II}

During the pontificate of John Paul II, a book by Karol Wojtyla was published in Krakow, the text of which was written in 1949. These are records of lectures given in the academic ministry in Krakow, entitled „Considerations on the Essence of Man”.

This text seemed astonishing for several reasons. It was another ,discovered', previously unknown text by Karol Wojtyla. As a text of a young man and a priest, it is a testimony to the great clarity and depth of thought of a young philosopher and pastor. Finally, it remains a testimony to the aforementioned and so characteristic of Karol Wojtyla's method of thinking and method of lecture. The author himself states: „In choosing man as the theme of our considerations, we must immediately state that we can deal with this theme from the viewpoint of man's fate or of his essence. We choose the latter. Man's fate is in great measure the consequence of his essence ${ }^{2}$.

It is precisely this quest to explore the essence, the transition „from phenomenon to foundation" (as John Paul II later described it in his encyclical "Fides et ratio"), that is the peculiar methodological key of the Wojtyla's thought. It is at the same time a proposal that was put forward by John Paul II, especially in his moral encyclical Veritatis splendor.

\footnotetext{
' K. Wojtyła, Considerations on the Essence of Man, Kraków 1999.
}

2 Ibidem, 21. 
przez Jana Pawła II, zwłaszcza w jego encyklice moralnej „Veritatis splendor".

W tej właśnie encyklice, fundamentalnie ważnej dla teologii moralnej, poddanej perturbacjom doby posoborowej, człowiek został ukazany, a może przypomniany, jako ten, który jest nie tylko przedmiotem norm, które regulują jego działanie moralne. Jest kimś, kto jest zdolny w swoim działaniu moralnym wyrazić siebie jako osobę. Można bez przesady stwierdzić, że myślenie personalistyczne jest cechą charakterystyczną kultury zachodniej. Pytanie jednak czy ten swoisty kod kulturowy nie został naruszony pod wpływem charakterystycznego zwrotu w dziejach myśli europejskiej w dobie nowożytnej. „Przełom kartezjański” w filozofii, który wyraził się zwrotem W stronę świadomości i podmiotowości, oznaczał odejście nie tylko od analizy bytu. Naznaczony był również przejściem od akcentu wspólnotowego w myśleniu o osobie do myślenia o niej w kategoriach indywidualnego, niepowtarzalnego jestestwa ${ }^{3}$.

\section{REORIENTACJA POJĘĆ I MYŚLENIA O OSOBIE}

Warto może w tym miejscu przypomnieć, że wnikliwa analiza pierwotnych greckich i łacińskich znaczeń osoby (w sposób bardzo charakterystyczny złączona z pojęciem twarzy) wskazuje na głębię o pewnej określonej treści, wyrazistość, zażyłość bezpośredniego spotkania osobowego i wyjątkową wartość (godność). Przy tym, jakkolwiek wcześnie dostrzeżono fakt, że godność dotyczy tylko rzeczywistości w zakresie tzw. natur rozumnych, to jednak długo miano trudności z ukazaniem elementu konstytutywnego dla osoby. Pojmując ją jako jednostkę, uznawano za jej specyficzną cechę ,nieudzielalność" drugiemu bytowi bytową autonomiczność i podmiotową zupełność w obrębie gatunku. Ten nurt refleksji znalazł odbicie w najsłynniejszej definicji osoby autorstwa Boecjusza. Podał on definicję osoby jako jednostkowej substancji rozumnej (intelektualnej) natury (rationalis naturae individua substantia). Według Akwinaty

${ }^{3}$ Cfr. Arystoteles, Zoologia. Historia Animalium, Warszawa 1982, 491, 911. 
It is in this encyclical, which is of fundamental importance for moral theology and which was subjected to the perturbations of the Post-Conciliar era, that man is shown, or perhaps reminded, as the one who is not only subject to the norms that regulate his moral action, but also someone who is able to express himself in his moral acts as a person. One can truly say with no exaggeration that personalistic thinking is a characteristic feature of Western culture. However, the question is whether this peculiar cultural code has not been violated under the influence of a characteristic turn in the history of European thought in modern times. „The ,Cartesian breakthrough' in philosophy, which expressed itself as a turn towards consciousness and subjectivity, meant a departure not only from the analysis of being. It was also marked by a shift from a communal emphasis in thinking about the person to thinking about him in terms of an individual, unique being ${ }^{3}$.

\section{REORIENTING CONCEPTS AND THINKING ABOUT THE PERSON}

Here one should perhaps recall that a thorough analysis of the original Greek and Latin meanings of a person (in a very characteristic way combined with the notion of a face) indicates a depth with a certain content, clarity, intimacy of a direct personal meeting and exceptional value (dignity). At the same time, although the fact that dignity only applies to reality in the scope of so-called „rational natures" was recognised early on, the difficulty in showing the constitutive element of the person was long term. In understanding that the person is an individual, it was considered to be a specific feature of his ,inaccessibility” to the other being, the autonomy and subjective completeness within the species. This current of reflection appears in the most famous definition of the person by Boethius. He provided a definition of a person as an individual substance of rational (,intellectual”) nature (rationalis naturae individua substantia).

${ }^{3}$ Cf. Aristotle, Historia Animalium, Warsaw 1982, 491, 911. 
elementem decydującym o osobie jest jednostkowe istnienie tej oto natury rozumnej. Osoba jest, według Tomasza, równocześnie bytem samoistnym (o własnym akcie istnienia), rozumnym i indywidualnym, a przez to jest szczytową formacją bytową ${ }^{4}$.

W czasach nowożytnych zjawiska takie jak: głęboka depresja w Europie schyłku Średniowiecza pod wpływem Wielkiej Zarazy, konflikty między Kościołem a Imperium, wojny międzynarodowe i między grupami społecznymi i inne spowodowały zachwianie równowagi w dominujących instytucjach, przede wszystkim w Kościele. Pod wpływem podziałów Kościoła zaczęto rozważać i akcentować grzeszność jednostki. W ten sposób osłabiono wcześniejszą skłonność introspektywną. Ponadto początkowo wyakcentowano zdeprawowanie i bezwartościowość człowieczeństwa.

W drodze reakcji przyniosło to pewien nurt myślowy, który wytwarzał postawy i wartości odtąd trwale już obecne w kulturze ludzkiej. Przede wszystkim Kartezjusz i Lock dokonali próby zakotwiczenia poznania ludzkiego w jaźni jako podstawie wszelkiej osiągalnej pewności. Zapoczątkowało to nowy rodzaj indywidualizmu, który przejawiał się w kontestacji szerokich instytucji społecznych i próbie kierownictwa intelektualnego (cfr. Voltaire, Rousseau). Do XVIII w. ukształtował się zatem nowy indywidualizm. W ekonomice i polityce za punkt odniesienia uważano układy zasadniczo niezależnych jednostek związanych umową społeczną, w etyce

${ }^{4}$ Należy zwrócić uwagę, w związku z teorią tomistyczną, na problem możliwości utożsamienia osoby z człowiekiem, bądź osoby z duszą. W pierwszej z tych kwestii można stwierdzić, że o ile każdy człowiek jest osobą, o tyle nie ma relacji odwrotnej (osobą jest Bóg czy anioł, nie tylko człowiek). Także nie da się utożsamić duszy z osobą, gdyż dusza jest tylko jakby „częścią” rozumnej natury ludzkiej, a o osobie decyduje rozumna natura „w całości bytowej”. Cfr. M. Gogacz, Wokót problemu osoby, Warszawa 1974, 170173. Myśl św. Tomasza z Akwinu stanowiła syntezę i szczytowe zarazem osiągnięcie myśli średniowiecznej w kulturze europejskiej. Rangę pojęciu osoby, utraconą w czasach nowych trendów odrodzeniowych, przywróciła dopiero współczesność, zwłaszcza w postaci chrześcijańskiego egzystencjalizmu i personalizmu. 
According to Aquinas, the decisive element for a person is the individual existence of his intelligent nature. As Thomas Aquinas states, a person is, at the same time, an autonomous entity (with its own act of existence), rational and individual, and thus is the peak formation of the entity ${ }^{4}$.

In modern times, phenomena such as the deep depression in Europe at the end of the Middle Ages under the influence of the Great Plague, conflicts between the Church and the Empire, international and intercommunity wars as well as many others led to an imbalance in the dominant institutions, above all in the Church. Under the influence of the divisions of the Church, the sinfulness of the individual began to be considered and accentuated. In fact, the previous introspective inclination weakened. Additionally, the depravity and worthlessness of humanity was initially highlighted.

This brought about a kind of thought-provoking current that produced attitudes and values that were now firmly established in human culture. Above all, Descartes and Lock tried to anchor human cognition in the self as the basis of all attainable certainty. This initiated a new kind of individualism, which manifested itself in the contestation of broad social institutions and the attempt of intellectual leadership (Cf. Voltaire, Rousseau). A new kind of individualism developed by the 18th century. In economics and politics, the systems of fundamentally independent individuals bound by the social contract were considered as a point of reference, in ethics a fully autonomous

${ }^{4}$ In connection with Thomistic theory, attention should be paid to the problem of the possibility of identifying a person with a person or a person with a soul. The first of these issues reveals that while every human being is a person, there is no reverse relationship (a person is God or an angel, not just a person). It is also impossible to identify the soul with the person, because the soul is only a kind of „part" of the rational human nature, and the person is determined by the rational nature of the „whole being”. Cf. Gogacz, M. (1974) Around the Problem of the Person, Warsaw, 170,173. The thought of St. Thomas Aquinas was a synthesis and the peak achievement of medieval thought in European culture. The importance of the notion of person, lost in the times of new revival trends, was only restored to the present day, especially in the form of Christian existentialism and personalism. 
za czynnik moralny uznawano w pełni autonomiczną jednostkę. Pierwszoplanowym aspektem tego nowego indywidualizmu stała się samoświadomość.

Jednostka ludzka rozumiana w czasach średniowiecza w kategoriach duchowej głębi z jej bezpośredniością i czułością została wyparta przez rozumienie w kategoriach prywatności, materialnego ujednostkowienia, psychologicznego wyodrębnienia. Zaakcentowanie prywatności doprowadziło do pewnego rodzaju izolacji, mimo wielu prób do dzisiaj właściwie nieprzełamanej, traktowanej jako istotny problem.

Subiektywna świadomość została ujęta jako sama odmiana podmiotowości, rodzaj wewnętrznej, uzewnętrzniającej się wyjątkowości. Te kategorie zastąpiły średniowieczne, teologiczne pojęcie duchowej głębi wyrastającej z intymnej zażyłości z Bogiem.

Proces analizowania złożonej rzeczywistości osoby z przyznaniem pierwszorzędnej roli świadomości, a w konsekwencji rozumowi, miał swoje niezwykle dogłębne znaczenie dla refleksji antropologicznej, zarówno w płaszczyźnie filozoficznej, jak i teologicznej. Jan Paweł II sumarycznie ocenia ten okres w swoim wywiadzie książkowym: „Mniej więcej sto pięćdziesiąt lat po Kartezjuszu stwierdzamy, jak wytaczono poza nawias to wszystko, co jest istotowo chrześcijańskie w tradycji myśli europejskiej. Protagonistą staje się tutaj epoka oświeceniowa we Francji. Oświecenie to definitywna afirmacja czystego racjonalizmu. [...].

[...] proces odchodzenia od Boga ojców naszych, od Boga Jezusa Chrystusa, Ewangelii i Eucharystii, nie oznaczał zerwania z Bogiem bytującym poza światem.[...].

Ale ten Bóg jest stanowczo Bogiem poza-światowym. [...] Co to oznaczało? Oznaczało to, że człowiek powinien żyć, kierując się tylko własnym rozumem, tak jakby Bóg nie istniał"s.

Powyżej zarysowany proces, zwany zwrotem antropocentrycznym, wskazuje na dwie, integralnie ze sobą związane płaszczyzny: antropologiczną i etyczną. Nie sposób w tym miejscu nie dostrzec,

5 Jan Paweł II, Przekroczyć próg nadziei, Lublin 1994, 56-57. 
individual was considered as a moral factor. The primary aspect of that new individualism was self-awareness.

A human being understood in medieval times in terms of spiritual depth with its directness and tenderness was replaced by an understanding in terms of privacy, material unification, and psychological separation. The focus on privacy resulted in a kind of isolation, in spite of many attempts that have not been broken down to this day, which is considered a significant problem.

The subjective consciousness has been captured as a variety of subjectivity itself, a kind of internal, outwardly unique. These categories replaced the medieval, theological notion of spiritual depth, which grew out of intimate closeness to God.

The process of analysing the complex reality of a person with the primary role of consciousness and, consequently, reason, has had an extremely profound impact on anthropological reflection, both philosophically and theologically. John Paul II assesses that period in his book interview:

„In fact, about 150 years after Descartes, all that was fundamentally Christian in the tradition of European thought had already been pushed aside. This was the time of the Enlightenment in France, when pure rationalism held sway. [...].

[...] the process of turning away from the God of the Fathers, from the God of Jesus Christ, from the Gospel, and from the Eucharist did not bring about a rupture with a God who exists outside of the world. [...]. 
że wszelka redukcja w pierwszej z nich, powoduje określone konsekwencje w drugiej. Trzeba także podkreślić, że proces zwrotu antropocentrycznego jest procesem trwającym, choć nie wyłącznym we współczesnej antropologii. Warto w tym miejscu przywołać, niejako $\mathrm{w}$ formie syntezy prezentowanego napięcia wymiaru dialogalnego i jednostkowego osoby ludzkiej, słowa Jana Pawła II z jego Listu do Rodzin. Słowa te wręcz demaskują samo sedno sporu o człowieka dzisiaj. Po jednej stronie owego sporu można odnaleźć uznanie bezwzględnego priorytetu wolności w jednostce ludzkiej, choćby mocą traktowania innych (drugich) użytecznościowo. Po drugiej natomiast jawi się wizja człowieka respektującego bezwzględny prymat miłości - daru i afirmacji. „Indywidualizm oznacza takie użycie wolności, w którym podmiot czyni to, co sam chce. On sam też «ustanawia prawdę» tego, co chce. Nie przyjmuje, aby ktoś «chciał», wymagał od niego w imię obiektywnej prawdy. Nie chce drugiemu «dawać», stawać się darem «bezinteresownym» w prawdzie. Indywidualizm pozostaje egocentryczny i egoistyczny. Antyteza pomiędzy nim a personalizmem rodzi się nie tyle na gruncie teorii, ile na gruncie «etosu». «Etos» personalizmu jest altruistyczny. W jego zasięgu osoba nie tylko zdolna jest stawać się darem dla drugich, ale co więcej - znajduje w tym radość. Jest to ta radość, o jakiej mówi Chrystus (cfr. J 15,11; 16,20. 22)”6. Wizja osoby, o którą zatem toczy się zasadniczy spór w „Veritatis splendor”, to wizja człowieka ujmowanego albo przez absolutną kategorię wolności, albo też znajdującego swoje samorozumienie w kategorii miłości - rozumianej jako bezinteresowny dar z siebie samego. Jest to zarazem spór o osobę pojmowaną indywidualistycznie, bądź integralnie - w jej wymiarze zarówno jednostkowym, jak i wspólnotowym. Papież zwraca przy tym $\mathrm{w}$ encyklice uwagę na wynikającą $\mathrm{z}$ antropologii indywidualistycznej „etykę indywidualistyczną, według której każdy człowiek staje wobec własnej prawdy, różnej od prawdy innych. Posunięty do skrajnych konsekwencji, indywidualizm prowadzi do zaprzeczenia

${ }^{6} \mathrm{LdR} 14$ 
This God, however, is decidedly a God outside of the world. [...] The consequence was that man was supposed to live by his reason alone, as if God did not exist." 5

The process outlined above, called the anthropocentric phrase, points to two integrally related planes: anthropological and ethical ones. Here it is impossible not to see that any reduction in the former causes specific consequences in the latter. It should also be stressed that the process of the anthropocentric turn is an ongoing process, although not exclusive in contemporary anthropology. In this regard, it is worth recalling the words of John Paul II from his Letter to Families, as if in the form of a synthesis of the presented tension in the dialogical and individual dimension of the human person. These words even expose the very essence of the dispute about man today. On one side of this dispute, one can find recognition of the absolute priority of freedom in the human individual, if only by treating other people (,the others') in a useful way. On the other hand, there is a vision of a man who respects the absolute primacy of love - a gift and affirmation.

„Individualism means the freedom in which the subject does what he or she wants. He also, establishes the truth' of what he wants. He does not accept that someone, wants', he demands it in the name of objective truth. He does not want to ,give' to the other, or become a ,selfless' gift in the truth. Individualism remains egocentric and selfish. The antithesis between it and personalism is born not so much on the basis of theory as on the basis of ,ethos". The ,ethos" of personalism is altruistic. Within its reach, a person is not only able to become a gift to others, but

5 John Paul II, (1994) Crossing the Threshold of Hope, published originally in Italian by Arnoldo Mondadori Editore and in English by Alfred A. Knopf, Inc., distributed by Random House, Inc., New York Cit, 56-57. 
samej idei natury ludzkiej"7. Prezentowany tymczasem przez Jana Pawła model osoby, proklamowany na kartach „Veritatis splendor” jest modelem bezwzględnie godności osoby ludzkiej. Takie sformułowanie, wspólne niewątpliwie od strony deklaratywnej dla wszelkich odmian personalizmu, domaga się wszakże pogłębionej analizy.

\section{GODNOŚĆ OSOBY LUDZKIEJ}

Godność każdego człowieka, według doktryny chrześcijańskiej, jest konsekwencją faktu stworzenia człowieka na obraz i podobieństwo Boże. Czyn stwórczy Boga, pomimo ludzkiego grzechu, nie został zaprzepaszczony dzięki zbawczemu czynowi Syna Bożego, Jezusa Chrystusa. Temat „obrazu Bożego” w człowieku (,imago Dei") jest niezwykle ważny dla antropologii teologicznej. Ma wręcz znaczenie fundamentalne. Obejmuje w swoim zakresie zawartość treściową człowieczeństwa, którą język spekulatywny określa kategoriami rozumności, wolności, związku z wartościami (zwłaszcza moralnymi), cielesności oraz wspólnotowego wymiaru człowieka. Ponadto, z prawdy o byciu obrazem Boga wynikają niezwykle istotne konsekwencje, które dotyczą przeznaczenia człowieka, co z kolei określa jego powołanie. Wskazane zagadnienia wyznaczają dalszy tok niniejszej refleksji.

\section{Człowiek jako imago Dei}

Omawiając zadania posługi teologów moralistów w Kościele, autor encykliki „Veritatis splendor” wskazuje na ścisłą zależność tej dyscypliny teologicznej od antropologii. W tej zależności zawarte są zarazem przesłanki sugerujące konkretny kształt myślenia antropologicznego. Tak więc teologowie moraliści „,zachowując ścisłą i niezbędną więź z teologią biblijną i dogmatyczną, mają (...) w swej naukowej refleksji podkreślać «aspekt dynamiczny moralności, to znaczy poświęcić szczególna uwagę odpowiedzi, jakiej na

\footnotetext{
7 VS 32.
} 
what is more, he finds joy in it. This is the joy that Christ speaks of (Cf. John 15,11; 16,20 22)"'.

Thus, the vision of the person about whom there is a fundamental dispute in ,Veritatis splendor' is the vision of a person who is either caught up in the absolute category of freedom, or who finds his or her self-understanding in the category of love understood as an unselfish gift of self. It is at the same time a dispute over a person understood individually, or integrally, in his or her individual and community dimension. In his encyclical, the Pope draws attention to 'an individualist ethic, wherein each individual is faced with his own truth, different from the truth of others. Taken to its extreme consequences, this individualism leads to a denial of the very idea of human nature' . The model of the person presented by John Paul, proclaimed on the pages of „Veritatis splendor", is a model of absolute dignity of the human person. Such a formulation, which is undoubtedly common to all forms of personalism from a declarative point of view, demands, however, an in-depth analysis.

\section{HUMAN DIGNITY}

The dignity of every human being, according to Christian doctrine, is a consequence of the fact that man was created in the image and likeness of God. God's creative act, despite human sin, was not destroyed thanks to the saving act of the Son of God, Jesus Christ. The theme of „God's image" in man (,,imago Dei") is extremely important for theological anthropology. It is even of fundamental importance. It covers in its scope the content of humanity, which is defined by speculative language in terms of categories of reasonableness, freedom, connection with values (especially moral ones), carnality and the community dimension of man. In addition, the truth of being an image of God has extremely important consequences which relate

${ }^{6}$ LdR 14. 
Boże wezwanie winien udzielić człowiek w procesie swego wzrastania w miłości, w łonie zbawczej wspólnoty. W ten sposób teologia moralna zyska wewnętrzny wymiar duchowy, uwzględniając potrzebę pełnego rozwoju imago Dei, ukrytego w człowieku oraz prawa procesu duchowego, opisanego przez chrześcijańską ascetykę i mistykę» ${ }^{8} "$.

W centrum antropologii chrześcijańskiej jawi się zatem kategoria imago Dei. Wyrażony przez nią wymiar stworzenia osoby w jej wizji jako podmiotu moralnego obejmuje nie tylko oczywiste odniesienie do faktu, że jesteśmy stworzeni przez Boga Ojca, ale także wyraża prawdę, że jesteśmy stworzeni przez Chrystusa i w Chrystusie. „«Chrystus... już w samym objawieniu tajemnicy Ojca i Jego miłości objawia w pełni człowieka samemu człowiekowi i okazuje mu najwyższe jego powołanie» [KDK 22]. W Chrystusie «obraz Boga niewidzialnego» (Kol 1,15), człowiek został stworzony «na obraz i podobieństwo» Stwórcy. W Chrystusie, Odkupicielu i Zbawicielu, obraz Boży, zniekształcony w człowieku przez grzech pierwszy, został odnowiony w swoim pierwotnym pięknie i uszlachetniony łaską Bożą [cfr. KDK 22]"10. Tak pojęty stwórczy wymiar osoby jest fundamentem bezpośrednich relacji człowieka z Bogiem w Jezusie Chrystusie. Ukazuje także aktualną egzystencję człowieka jako egzystencję stworzenia Bożego. Egzystencja ludzka w swej całości pozostaje od Boga i w Bogu, a jednocześnie przez Chrystusa i w Chrystusie. Pozwala to stwierdzić, że „człowiek zostaje obdarzony najwyższą godnością, która jest zakorzeniona w wewnętrznej więzi łączącej go ze Stwórcą; jaśnieje w nim odblask rzeczywistości samego Boga"'1.

\footnotetext{
${ }^{8}$ Św. Kongregacja Wychowania Katolickiego, La formazione teologica dei futuri sacerdoti, n. 100. Cfr. także nn. 95-101, które przedstawiają perspektywy i warunki skutecznej pracy nad odnową teologiczno-moralną.

9 VS 111.

${ }^{10}$ KKK 1701.

11 EV 34.
} 
to man's destiny, which in turn determines his vocation. The issues identified are the further course of this reflection.

\section{Man as imago Dei}

In discussing the tasks of the ministry of moralist theologians in the Church, the author of the encyclical ,Veritatis splendor' points to the close dependence of this theological discipline on anthropology. This dependence also contains premises suggesting a specific shape of anthropological thinking. Thus, moral theologians:

„while maintaining a close and necessary connection with biblical and dogmatic theology, are to (...) in their scientific reflection emphasize « the dynamic aspect of morality, that is to say, to devote particular attention to the answer that man should give to God's call in the process of his growth in love, in the bosom of salvation. In this way moral theology will gain an internal spiritual dimension, considering the need for the full development of imago $D e i$, hidden in man and the law of the spiritual process, as described by Christian ascetics and mysticism $» " 7 "$.

At the heart of Christian anthropology, therefore, is the category of imago Dei. The dimension it expresses of the creation of the person in its vision as a moral subject includes not only the obvious reference to the fact that we are created by God the Father, but it also expresses the truth that we are created by Christ and in Christ. „« Jesus Christ... "in the very revelation of the mystery of the Father and of his love, fully reveals man to himself and brings to light his most high calling"» [Gaudium et spes 22]. It is in Christ, «the image of the invisible God».

7 St. Congregation for Catholic Education, La formazione theologica dei futuri sacerdoti, n. 100. Cf. also nn. 95-101, which present perspectives and conditions for effective work on the theological and moral renewal.

8 VS 111. 
W perspektywie moralnej stworzenie jawi się jako akt mówienia Boga do człowieka. Mowa Boga dokonuje się dwojako: poprzez rzeczy stworzone (słowa wypowiedziane), a także poprzez człowieka (nie tylko jest to słowo wypowiedziane, ale i zarazem słowo mówiące, jako jedyne zdolne do mówienia od siebie, w konsekwencji zdolne do odpowiedzi). Tradycja biblijna zwraca uwagę, że Bóg stwarzając człowieka nazywa go (nadaje mu imię człowieka). Ten fakt oznacza Boże wymaganie, by człowiek był i żeby był człowiekiem. Dialog Boga z człowiekiem dokonuje się nieustannie za pośrednictwem sumienia rozpoznającego głos Boga jako prawo. „Każdy człowiek jest zobowiązany do kierowania się tym prawem, które rozbrzmiewa w sumieniu i które wypełnia się w miłości Boga i bliźniego. Życie moralne świadczy o godności osoby" ${ }^{\prime 2}$. Człowiek w perspektywie stworzenia jawi się zatem jako naturalne wymaganie Boga, a równocześnie jako wolna i rozumna odpowiedź Bogu. Doskonałym przykładem takiej odpowiedzi Bogu - wolnej, rozumnej, a nade wszystko wyrażonej miłością, jest wzór Jezusa Chrystusa (cfr. 2 Kor 1,1920). Chrystus jest szczególnym prawzorem komunikacji i dialogu człowieka z Bogiem.

Jednak najbardziej doniosłą prawdę objawioną w Biblii stanowi ta, która traktuje człowieka jako obraz Boga. Wyrażają ją dwa teksty z Księgi Rodzaju: Rdz 1, 2627 i Rdz 5, 12. 9,6. Dzieje myśli teologicznej przyniosły szereg interpretacji dotyczących rozumienia w tych opisach „obrazu”. Reasumując konkluzje dawnych i aktualnych teorii, można ostatecznie stwierdzić, że „pojęcie «obrazu Bożego» wyraża zarówno powszechną wolę zbawczą Boga względem każdego człowieka jak i wartość w sobie każdej osoby ludzkiej. (...)

Byćobrazem znaczy, że człowiek nosi wpisaną w swoje byćstworzeniemBożym wolę stwórczą Boga, która jest planem zbawczym lub wezwaniem do dialogu. Byćczłowiekiem to być obrazem Bożym, to także relacja $\mathrm{w}$ cielesności istnienia.

Ludzkość ma ten cel: dialog z Bogiem. Ludzie nie są stworzeni dla innych celów (...), poza Bogiem. Bóg jednak nie jest celem, który

12 KKK 1706. 
(Col 1:15), that man has been created ,in the image and likeness” of the Creator. It is in Christ, Redeemer and Saviour, that the divine image, disfigured in man by the first sin, has been restored to its original beauty and ennobled by the grace of God [cf. Gaudium et spes 22] $]^{9}$. The creative dimension of a person understood in this way is the foundation of direct relations between man and God in Jesus Christ. It also shows man's current existence as the existence of God's creation. Human existence in its entirety remains from God and in God, and simultaneously through Christ and in Christ. Therefore, it can be stated that "the dignity of the human person is rooted in his/ her creation in the image and likeness of God. It is fulfilled in his/ her vocation to divine beatitude" 10 .

From a moral perspective, creation appears to be an act in which God speaks to man. God's address is made in two ways: through created things (spoken words), and also through man ( not only is it a spoken word, but also a word that speaks, as the only ones capable of speaking from themselves, and consequently able to respond). Biblical tradition points out that God, by creating man, calls him (gives him the name of man). This fact means God's requirement for man to be and to be human. The dialogue between God and man is constantly taking place through the conscience which recognizes the voice of God as law. „Everyone is obliged to follow this law, which makes itself heard in conscience and is fulfilled in the love of God and of neighbour. Living a moral life bears witness to the dignity of the person"11. In the perspective of creation, therefore, man appears to be a natural requirement of God and, at the same time, a free and rational response to God. A perfect example of such a response to God, i.e. free, rational and above all expressed in love, is the model of Jesus Christ (Cf. 2 Cor 1:19 20). Christ is a particular example of communication and dialogue between man and God.

\footnotetext{
9 CCC 1701.

${ }^{10} \mathrm{EV} 34$.

${ }^{11}$ CCC 1706.
} 
czyni z człowieka narzędzie: człowiek jest jedynym stworzeniem, którego Bóg chciał dla niego samego"13.

Idea dialogu człowieka z Bogiem stanowi biblijny paradygmat encykliki „Veritatis splendor”. Jest to dialog wpisany w rzeczywistość spotkania Chrystusa z bogatym młodzieńcem. Obraz ten nadaje prezentacji myśli papieskiej $\mathrm{w}$ analizowanym dokumencie rys do głębi personalistyczno-chrystologiczny. Pozwala to zauważyć dalej, że ujęcie takie nie akcentuje ani prawa (pojętego legalistycznie) jako opozycji względem osoby, ani czysto formalnej powinności jako imperatywu moralnego (choćby owa powinność miała swoje uzasadnienie w godności osoby ludzkiej). Naczelną normą, zarówno personalistyczną, jak i chrystologiczną zarazem jest prawo wcielone w osobie Jezusa Chrystusa ${ }^{14}$.

Sapiencjalny tekst: „Dla nieśmiertelności Bóg stworzył człowieka uczynił go obrazem (eikona) swej własnej wieczności...” (Mdr 2,26) jest dobitnym znakiem dowartościowania człowieka w myśli teologicznej Starego Testamentu. Myśl ta nie przesłania prawdy, że obraz - imago Dei został przez samego człowieka zniszczony dziełem grzechu. Nowy Testament może jednak w nowej, soteriologicznej perspektywie, podjąć ten temat. Człowiek przestaje być obrazem Boga na skutek własnego grzechu. Ale może na nowo zyskać w sobie ten obraz dzięki nowemu stworzeniu w chrzcie (Kol 3,10). Dokonuje się to w wyniku działania Jezusa. Obraz Boga w Nowym Testamencie, w takim razie, zakłada powinność uczestniczenia w Chrystusie. To właśnie On jest przede wszystkim obrazem Boga $(\mathrm{Kol} 1,15)^{15}$.

Stąd też wyrasta dogłębne przekonanie Autora „Veritatis splendor”, iż oparciem dla działalności Kościoła, z miłością wspomagającej

13 A. Bonora, Człowiek obrazem Boga w Starym Testamencie, „Communio“ 2:1982 nr $2(8), 13$.

${ }^{14}$ Cfr. J. Seifert, Blask prawdy jako fundament działania moralnego. O encyklice papieża Jana Pawła II ,Veritatis splendor”, w: Jan Paweł II, Veritatis splendor. Tekst i komentarze, Lublin 1995, 174.

15 Biblijne pojęcie obrazu (gr. eikon) nie tyle wyraża ideę doskonałego podobieństwa, co ideę reprezentacji. Chrystus jest zatem Tym, który objawia prawdziwą postać Boga w kategoriach ludzkich i ukazuje relację do świata stworzonego. 
However, the most momentous truth revealed in the Bible is the one that treats man as an image of God. It is expressed in two texts from Genesis: Genesis 1, 2627 and Genesis 5, 1 2. 9,6. The history of theological thought has brought a number of interpretations concerning the understanding of ,image" in these descriptions. Summing up the conclusions drawn from past and present theories, it can be ultimately stated that ,the concept of the ,image of God" expresses both the universal salvific will of God for every human being and the value in itself of every human person. (...)

To be an image means that man carries God's creative will, inscribed in his being a creature, which is a salvation plan or a call for dialogue. To be human is to be an image of God, it is also a relationship in the body of existence.

Humanity has this objective: dialogue with God. Human beings are not created for other purposes (...) than God. But God is not the purpose that makes man an instrument: man is the only creature that God wanted for himself"'12.

The idea of human dialogue with God is the biblical paradigm of the Encyclical ,Veritatis splendor'. It is a dialogue inscribed in the reality of Christ's encounter with the rich young man. This picture gives the presentation of papal thought in the analysed document a personalist-christological depth. Thus, it can be seen further on that such an approach accentuates neither the law (understood legally) as an opposition to the person, nor a purely formal duty as a moral imperative (even if this duty has its justification in the dignity of the human person). The supreme norm, both personalistic and Christological, is the law incarnated in the person of Jesus Christ ${ }^{13}$.

Sapienese text: „For God created man to be immoral, and made him to be an image (Greek: eikon) of his own eternity ..." (Wisdom

12 Bonora, A. Człowiek obrazem Boga w Starym Testamencie, „Communio“ 2:1982 no. 2 (8), 13.

${ }^{13}$ Cf. Seifert, J. (1995) Blask prawdy jako fundament działania moralnego. O encyklice papieża Jana Pawła II ,,Veritatis splendor”, in: Jan Paweł II, Veritatis splendor. Tekst i komentarze, Lublin, 174. 
wiernych w formacji sumienia, które w wydawaniu sądów i kształtowaniu decyzji winno kierować się prawdą, jest szczególna kontemplacja Chrystusa. Jest to zresztą akcent tak bardzo zresztą charakterystyczny dla myśli Jana Pawła II, wyrażonej w programowej encyklice „Redemptor hominis”: „Odkupiciel człowieka Jezus Chrystus jest ośrodkiem wszechświata i historii. Do Niego zwraca się moja myśl i moje serce w tej doniosłej godzinie dziejów, w której znajduje się Kościół i cała wielka rodzina współczesnej ludzkości"16.

\section{Egzystencja w Chrystusie}

Chrystus jest doskonałą ikoną Boga Niewidzialnego, co oznacza, że nie jest tylko wierną kopią, ale posiada zalety oryginału i władny jest dokonywać upodobnienia do oryginału do Boga. W tekstach św. Pawła istnieją takie, które mówią o przyoblekaniu się w Chrystusa (cfr. Kol 3,10; Rz 13,14) ${ }^{17}$. Pozwala to Janowi Pawłowi II z mocą powtórzyć w encyklice „Veritatis splendor”: „Oparciem dla (...) dzieła Kościoła (...), są nie tyle wypowiedzi doktrynalne czy pasterskie wezwania do czujności, ile nieustanne wpatrywanie się w Chrystusa Pana. Kościół każdego dnia wpatruje się z niesłabnącą miłością w Chrystusa, w pełni świadom, że tylko w Nim znaleźć może prawdziwe i ostateczne rozwiązanie problemu moralnego"18.

Dzięki takiemu ujęciu wizja moralności chrześcijańskiej, zgodnie ze wskazaniami „Optatam totius” ukazuje „wzniosłość powołania wiernych w Chrystusie" i integralnie wiąże się z płaszczyzną duchowości chrześcijańskiej. Chrześcijanin w tej wizji jawi się jako człowiek wiary, „na którego obliczu jaśnieje blask Boży”19.

Określenie nowego sposobu życia chrześcijanina dokonuje się zatem - co trzeba bardzo wyraźnie podkreślić - nie przez prawo

16 RH 1.

17 Cfr. J.K. Pytel, Człowiek obrazem Boga w Nowym Testamencie, „Communio” 2:1982 nr 2(8), 16-21.

18 VS 85.

19 VS 90. 
$2: 26)$ is a clear sign of the appreciation of man in the theological thought of the Old Testament. This thought does not obscure the truth that the image - imago Dei - was destroyed by man himself by sin. However, the New Testament can take up this subject in a new, soteriological perspective. Man ceases to be an image of God because of his own sin. But he can gain this image in himself anew through a new creation in baptism (Colossians 3:10). This is done through the action of Jesus. The image of God in the New Testament, in that case, presupposes the obligation to participate in Christ. It is He who is above all the image of God (Colossians 1:15). ${ }^{14}$.

This is why the author of Veritatis splendor is deeply convinced that a special contemplation of Christ is the basis for the Church's activity, with love supporting the faithful in the formation of conscience, which should be guided by the truth in making judgments and shaping decisions. It is, moreover, so characteristic of the thought of John Paul II, expressed in the programmatic encyclical Redemptor hominis: "THE REDEEMER OF MAN, Jesus Christ, is the centre of the universe and of history. To him go my thoughts and my heart in this solemn moment of the world that the Church and the whole family of present-day humanity are now living." 15 .

\section{Existence in Christ}

Christ is the perfect icon of the Invisible God, which means that he is not just a faithful copy, but has the qualities of the original and is capable of conforming to God. In St Paul's texts there are those that speak of putting on the Lord Jesus Christ (Cf. Col 3:10; Rom

14 The biblical concept of the image (gr. eikon) does not so much express the idea of perfect similarity, but the idea of representation. Christ is therefore the One who reveals the true image of God in human terms and shows the relationship to the created world.

${ }^{15}$ RH 1. 
rozumiane jako zwyczajowy przepis czy obyczajowy konformizm, ale poprzez rzeczywistość określaną jako imitatio Christi. Ukierunkowanie na tak określony cel staje się możliwe dzięki darowi Ducha Świętego udzielanego przez sakrament i modlitwę każdemu wierzącemu: ,[Jezus] daje poprzez Ducha Świętego łaskę udziału w Jego własnym życiu i miłości oraz obdarza człowieka mocą, by mógł świadczyć o Nim swoimi decyzjami i czynami"20.

Wymieniony wymiar egzystencji chrześcijańskiej ukazuje podmiot etyczny od strony aktualizacji, w odniesieniu do tego momentu, którym jest aktualna egzystencja człowieka w Chrystusie i nieustanne włączanie się w Chrystusa. Ten aspekt osobowości moralnej człowieka został z wyjątkową predylekcją ujęty w pierwszej części encykliki. Warto w tym miejscu przywołać choćby ilustratywny fragment tej papieskiej medytacji. „Sam Jezus podejmuje tu inicjatywę i wzywa, by iść za Nim. Ta zachęta skierowana jest przede wszystkim do tych, którym powierza On szczególna misję, poczynając od Dwunastu; ale jest też oczywiste, że miano ucznia Chrystusa przysługuje każdemu wierzącemu (cfr. Dz 6, 1). Dlatego naśladowanie Chrystusa jest pierwotnym i najgłębszym fundamentem chrześcijańskiej moralności: jak lud Izraela szedł za Bogiem, który prowadził go przez pustynię ku Ziemi Obiecanej (cfr. Wj 13, 21), tak uczeń ma iść za Jezusem, ku któremu pociąga go sam Ojciec (cfr. J 6, 44).

Naśladowanie to nie polega jedynie na słuchaniu nauki i na posłusznym przyjmowaniu przykazań. Oznacza ono coś bardziej radykalnego: przylgnięcie do osoby samego Jezusa, uczestnictwo w Jego życiu i przeznaczeniu, udział w Jego dobrowolnym i pełnym miłości posłuszeństwie woli Ojca. Naśladując przez wiarę Tego, który jest Mądrością wcieloną, uczeń Jezusa staje się naprawdę uczniem Boga (cfr. J 6, 45). Jezus bowiem jest światłością świata, światłem życia (cfr. J 8, 12); jest pasterzem, który prowadzi i karmi owce (cfr. J 10, 11-16); jest drogą, prawdą i życiem (cfr. J 14, 6), jest Tym, który prowadzi do Ojca, tak że zobaczyć Jego, Syna, znaczy zobaczyć Ojca (cfr. J 14,

20 VS 15; cfr. A. Siemieniewski, Coraz bardziej jaśniejąc, upodabniamy się do Jego obrazu, [w:] W prawdzie ku wolności, Wrocław 1994, 234-241. 
13:14) ${ }^{16}$. This allows John Paul II to strongly repeat in his encyclical „Veritatis splendor":

„This effort by the Church finds its support (...) not so much in doctrinal statements and pastoral appeals to vigilance, as in constantly looking to the Lord Jesus. Each day the Church looks to Christ with unfailing love, fully aware that the true and final answer to the problem of morality lies in him alone."17

This vision of Christian morality, as indicated by Optatam totius, shows the ,sublimity of the vocation of the faithful in Christ' and is integrally linked to the plane of Christian spirituality. In this vision, the Christian appears as a man of faith on whose face "the light of God's face shines". ${ }^{18}$

The definition of a new way of life for a Christian is therefore and this must be very clearly emphasised - not by law as a customary recipe or moral conformism, but by a reality described as imitatio Christi. Targeting a goal so defined becomes possible thanks to the gift of the Holy Spirit given by the sacrament and prayer to every believer: „[Jesus] through the Spirit, he gives the grace to share his own life and love and provides the strength to bear witness to that love in personal choices and actions". ${ }^{19}$

This dimension of Christian existence shows the ethical subject from the point of view of updating, in relation to this moment, which is man's current existence in Christ and his constant incorporation into Christ. This aspect of man's moral personality is exceptionally

\footnotetext{
${ }^{16}$ Cf. Pytel, J.K. Człowiek obrazem Boga w Nowym Testamencie, „Communio” 2:1982 no. 2(8), 16-21.

17 VS 85

18 VS 90.

19 VS 15; Cf. Siemieniewski, A. (1994) Coraz bardziej jaśniejąc, upodabniamy się do Jego obrazu, [in:] W prawdzie ku wolności, Wrocław, 234-241.
} 
6-10). Dlatego naśladować Syna, «obraz Boga niewidzialnego» (cfr. Kol 1, 15), znaczy naśladować Ojca"21.

Naśladowanie Chrystusa staje się zatem w ujęciu Ojca św. Jana Pawła II swoistą definicją ucznia Jezusa i formułą moralności chrześcijańskiej. Oznacza powinność pójścia drogą Jezusa, co wedle słów samego Pana oznacza: zaprzeć się siebie i wziąć krzyż (cfr. Mk 8, 34 par.).

Z powyższego wynikają pewne określone wnioski. Pierwszy z nich oznacza teologalną intencjonalność życia chrześcijańskiego. Oznacza to iż fakt, że podmiotowość człowieka wynika z mocy łaski Chrystusa, która stanowi o istocie człowieka wierzącego i ukierunkowuje go na miłość wskazuje, że łaska nie jest jedynie celem, ku któremu zmierza egzystencja, lecz jest źródłem dynamizmu i samym dynamizmem życia. Chrześcijanin zatem nie tyle działa zgodnie ze swoją rzeczywistością bycia chrześcijaninem, co raczej jego działanie jest aktualizacją, dokonywaniem tej rzeczywistości, którą jest on sam na ile jego życie jest włączeniem w Chrystusa.

Po drugie można dostrzec eklezjalne usytuowanie życia chrześcijańskiego, co zawiera się w tym, iż relacja między Chrystusem a chrześcijaninem z konieczności odnosi się także do stosunku Kościoła i chrześcijanina. Kościół jest aktualizacją i uobecnieniem rzeczywistości Chrystusa. Jest także historycznym, wspólnotowym i sakramentalnym uobecnieniem Chrystusa. Kościół wreszcie to kontekst i sytuacja, w której Chrystus dokonuje swojego widzialnego udzielania się człowiekowi; egzystencja chrześcijańska jest zatem eklezjalna w swej istocie. „Włączony w Chrystusa, chrześcijanin staje się czlonkiem Jego Ciała, którym jest Kościót (cfr. 1 Kor 12, 13. 27)"22.

Można wreszcie dostrzec w obrazie włączenia chrześcijanina, mocą naśladowania, w Chrystusa, charakterystyczną tensję eschatologiczną. Oznacza to, że życie ucznia Chrystusa wyraża w sobie ogólne napięcie całej historii zbawienia. Jest w nim zatem ,już

${ }^{21}$ VS 19. Cfr. F. Greniuk, Idea naśladowania Chrystusa, [w:] Veritatis splendor. Przestanie, 111-112.

${ }^{22}$ VS 21. 
predicated in the first part of the Encyclical. At this point, it is worth recalling at least an illustrative fragment of this papal meditation.

„It is Jesus himself who takes the initiative and calls people to follow him. His call is addressed first to those to whom he entrusts a particular mission, beginning with the Twelve; but it is also clear that every believer is called to be a follower of Christ (cf. Acts 6:1). Following Christ is thus the essential and primordial foundation of Christian morality: just as the people of Israel followed God who led them through the desert towards the Promised Land (cf. Ex 13:21), so every disciple must follow Jesus, towards whom he is drawn by the Father himself (cf. Jn 6:44)."

This imitation is not just about listening to science and obeying the commandments. It means something more radical: adherence to the person of Jesus himself, participation in his life and destiny, participation in his voluntary and loving obedience to the will of the Father.

"By responding in faith and following the one who is Incarnate Wisdom, the disciple of Jesus truly becomes a disciple of God (cf. Jn 6:45). Jesus is indeed the light of the world, the light of life (cf. Jn 8:12). He is the shepherd who leads his sheep and feeds them (cf. Jn 10:11-16); he is the way, and the truth, and the life (cf. Jn 14:6). It is Jesus who leads to the Father, so much so that to see him, the Son, is to see the Father (cf. Jn 14:6-10). And thus to imitate the Son, "the image of the invisible God" (Col 1:15), means to imitate the Father."20

20 VS 19. Cf. Greniuk, F. Idea naśladowania Chrystusa, [w:] Veritatis splendor. Przesłanie, 111-112. 
i jeszcze nie" dziejów ludzkości i świata. W tym kontekście życie człowieka wierzącego staje się współpracą w dziele spełnienia się tego ,jeszcze nie”. Eschatologia staje się zatem formą życia chrześcijańskiego w tym sensie, że u źródeł egzystencji ludzkiej jest zaproszenie do rozwoju, wzrostu, dynamizmu, którego etapami są poszczególne okresy historii zbawienia traktowane jako wydarzenia historii osoby ludzkiej.

Moralność życia staje się zatem integralnie związana z rzeczywistością eschatyczną. „Przykazanie wiąże się z obietnicą: w Starym Przymierzu przedmiotem obietnicy było objęcie na własność ziemi [...]; w Nowym Przymierzu przedmiotem obietnicy jest «królestwo niebieskie». Stwierdza to Jezus na początku «Kazania na Górze» [...]. Do tej samej rzeczywistości królestwa nawiązują słowa o «życiu wiecznym», które jest udziałem w życiu samego Boga: osiąga ono swoją doskonałość dopiero po śmierci, ale dla wierzącego jest już teraz światłem prawdy, źródłem sensu życia, zalążkiem uczestnictwa w pełni naśladowania Chrystusa" 23 .

Konkludując analizę treści biblijnych odsłaniających istotę moralności chrześcijańskiej Autor encykliki wydobywa istotne elementy Objawienia dotyczące porządku moralnego. „Są nimi: podporządkowanie czlowieka i wszystkiego co czyni-Bogu, Temu, który «jeden tylko jest Dobry»; zwiazek pomiędzy moralnym dobrem ludzkich czynów a życiem wiecznym; naśladowanie Chrystusa otwierające przed człowiekiem perspektywę doskonałej miłości, a wreszcie dar Ducha Świętego jako źródło i moc życia moralnego «nowego stworzenia» (cfr. 2 Kor 5, 17)"24.

Istota orędzia chrześcijańskiej moralności nie powinna być zatem traktowana w kategoriach nakazu czy legalizmu (etyki kodeksu). Przeciwnie, jest to moralność na wskroś i konstytutywnie personalistyczna, akcentująca wyjątkową wartość osoby powołanej do dialogu egzystencjalnego z Bogiem.

23 VS 12.

${ }^{24}$ VS 28. 
Imitating Christ thus becomes, in the view of Father John Paul II, a specific definition of a disciple of Jesus and a formula of Christian morality. It means the duty to follow the path of Jesus, which, according to the words of the Lord himself, means 'denying yourself and taking up your cross' (Cf. Mark 8, 34 par).

This leads to some specific conclusions. The first of these is the theological intentionality of Christian life. It means that the fact that man's subjectivity derives from the power of Christ's grace, which constitutes the essence of a believer and directs him towards love, indicates that grace is not only the purpose of existence, but is the source of dynamism and the very dynamism of life. A Christian, therefore, does not so much act in line with his reality of being a Christian, but rather his action is an updating, an accomplishment of that reality, which he is himself, inasmuch as his life is an incorporation into Christ.

Secondly, we can see the ecclesial position of the Christian life, which is that the relationship between Christ and a Christian inevitably also applies to the relationship between the Church and a Christian. The Church is the updating and making present of Christ's reality. It is also the historical, community and sacramental presence of Christ. The Church, finally, is the context and the situation in which Christ makes his visible contribution to man; Christian existence is therefore ecclesial in its essence. „Having become one with Christ, the Christian becomes a member of his Body, which is the Church (cf. Cor 12:13, 27)". ${ }^{21}$

Finally, we can see a characteristic eschatological tendency in the image of the inclusion of the Christian in Christ, by the power of imitation. This means that the life of a disciple of Christ expresses in itself the general tension of the whole history of salvation. There is, therefore, , already and not yet' in it the history of humanity and the world. In this context, the life of the believer becomes a cooperation in the work of fulfilling the ,not yet”. Eschatology therefore becomes a form of Christian life in the sense that at the source of human

${ }^{21}$ VS 21. 
Ta wartość staje się czytelna w perspektywie charakterystycznego dla chrześcijaństwa orędzia integrującego wiarę i moralność. Wysiłek intelektualno-pastoralny Jana Pawła II zmierza bowiem nie tylko w stronę ocalenia właściwej więzi relacji wolności i prawdy. Papież wskazuje wyraźnie, że „radykalne rozerwanie więzi między wolnością i prawdą, jest konsekwencją, przejawem i dopełnieniem innej, jeszcze bardziej niebezpiecznej i szkodliwej dychotomii - tej mianowicie, która oddziela wiare od moralności" "25. Rozdział ten jest charakterystyczny dla współczesnego sekularyzmu i wpisanej w ten prąd kultury umożliwiającej ludziom myśleć i żyć tak, jakby Bóg nie istniał. Sekularyzm XX wieku jest konkretnym terenem i wyzwaniem współczesnej, proklamowanej przez Kościół „nowej ewangelizacji”. U jej podstaw znajduje się zdaniem Jana Pawła II fundamentalnie ważna potrzeba integracji wiary i moralności - logosu i etosu chrześcijan naszych czasów. Ojciec św. stwierdza: „Trzeba ponownie odnaleźć i ukazać prawdziwe oblicze chrześcijańskiej wiary, która nie jest jedynie zbiorem tez wymagających przyjęcia i zatwierdzenia przez rozum. Jest natomiast poznaniem Chrystusa w wewnętrznym doświadczeniu, żywą pamięcią o Jego przykazaniach, prawdą, którą trzeba żyć. Słowo zresztą jest prawdziwie przyjęte dopiero wówczas, gdy wyraża się w czynach i urzeczywistnia w praktyce. Wiara to decyzja, która angażuje całą egzystencję. Jest spotkaniem, dialogiem, komunią miłości i życia między wierzącym a Jezusem Chrystusem: Drogą, Prawdą i Życiem (cfr. J 14, 6)"26.

Integracja wiary i moralności jest tematem - zdaniem jeszcze Karola K. Wojtyły jako uczestnika Soboru - centralnym i priorytetowym ${ }^{27}$. Zerwanie tego związku oznacza bowiem zablokowanie dynamizmu wiary, który zdąża niejako ze swej istoty do przeniknięcia całej osoby. Wiara bowiem, zgodnie z orzeczeniami Soboru „rozjaśnia wszystko nowym światłem i ujawnia Boży zamysł od-

25 VS 88.

26 VS 88.

27 „Problemem [...] kluczowym konkretnej egzystencji chrześcijańskiej jest wiązanie wiary z moralnością”. K. Wojtyła, U podstaw odnowy, Kraków 1988, 85. 
existence is an invitation to development, growth, dynamism, the stages of which are individual periods of salvation history treated as events in the history of the human person.

The morality of life therefore becomes integral to the eschatological reality.

„The commandments are linked to a promise. In the Old Covenant the object of the promise was the possession of a land[...]; In the New Covenant the object of the promise is the "Kingdom of Heaven", as Jesus declares at the beginning of the "Sermon on the Mount"[...]. This same reality of the Kingdom is referred to in the expression "eternal life", which is a participation in the very life of God. It is attained in its perfection only after death, but in faith it is even now a light of truth, a source of meaning for life, an inchoate share in the full following of Christ.".22

To conclude the analysis of biblical content revealing the essence of Christian morality, the author of the encyclical brings out important elements of Revelation concerning the moral order.

"These are: the subordination of man and his activity to God, the One who "alone is good"; the relationship clearly indicated in the divine commandments, between the moral good of human acts and eternal life; Christian discipleship, which opens up before man the perspective of perfect love; and finally the gift of the Holy Spirit, source and means of the moral life of the "new creation" (cf. 2 Cor 5:17)." ${ }^{23}$

The essence of the message of Christian morality should therefore not be treated in terms of precept or legalism (code ethics). On the

22 VS 12.

23 VS 28. 
nośnie do pełnego powołania człowieka; dlatego kieruje ona umysł do rozwiązań w pełni ludzkich" ${ }^{28}$. Integracja wiary i moralności jest najpełniejszym wyrazem integracji i konstytucji człowieka. „Innymi słowy, nie istnieje czlowiek oraz chrześcijanin, lecz chrześcijanin jest tajemniczym spełnieniem człowieka" ${ }^{29}$. Takie ujęcie nie oznacza przypisania człowieczeństwa wyłącznie chrześcijanom, ani też nie wyraża uznania wyższości aksjologicznej chrześcijan nad niechrześcijanami. Twierdzenia o braku rozdziału między chrześcijaninem a człowiekiem nie należy też interpretować w sensie, że to, co ludzkie jest bezpośrednio chrześcijańskie. Można zatem - od strony negatywnej - dostrzec, że w tak rozumianej integracji nie zawiera się ani skrajne rozumienie autonomii moralnej, ani radykalne ujecie „anonimowego chrześcijaństwa” ${ }^{30}$. Należy natomiast dostrzec w potrzebie integracji wiary i moralności specjalną drogę będącą inicjatywą Boga. Jest nią droga wprowadzenia człowieka w komunię z osobą Boga przez Jezusa Chrystusa. W tak pojętej drodze ku komunii pośredniczy Kościół.

Odkrycie treści wiary implikuje powinność świadectwa. „Wiara posiada również wymiar moralny: jest źródłem zgodnego z nią życiowego zaangażowania i zarazem takiego zaangażowania się domaga. Obejmuje i wydoskonala przyjęcie i zachowywanie Bożych przykazań. (...)

Poprzez życie moralne wiara staje się «wyznaniem», nie tylko wobec Boga, ale także przed ludźmi: staje się świadectwem"31.

Jan Paweł II z predylekcją, potwierdzaną także swoją posługą beatyfikacyjną i kanonizacyjną, kontynuuje ową refleksję nad szczególną więzią wiary i świadectwa, zogniskowaną w męczeństwie. „Więź między wiarą a moralnością ujawnia w pełni swój blask w bezwarunkowym poszanowaniu niezaprzeczalnych wymogów wyplywających z osobowej godności każdego człowieka, wymogów chronionych

${ }^{28} \mathrm{KDK} 11$.

29 R. Buttiglione, Myśl Karola Wojtyty, Lublin 1996, 299.

${ }^{30}$ Cfr. ibidem, 299-301.

31 VS 89. 
contrary, it is a thoroughly and constitutionally personalistic morality, emphasising the exceptional value of a person called to existential dialogue with God.

This value becomes clear from the perspective of a message characteristic of Christianity that integrates faith and morals. The intellectual and moral effort of John Paul II is not only aimed at saving the proper bond between freedom and truth. The Pope clearly points out that 'The attempt to set freedom in opposition to truth, and indeed to separate them radically, is the consequence, manifestation and consummation of another more serious and destructive dichotomy, that which separates faith from morality. ${ }^{24}$ This chapter is characteristic of modern secularism and of a culture inscribed in this current that enables people to think and live as if God did not exist. The secularism of the twentieth century is a specific area and challenge of the modern ,new evangelization” proclaimed by the Church. According to John Paul II, it is based on a fundamentally important need to integrate faith and morality - the logos and ethos of Christians of our times. The Holy Father states:

'It is urgent to rediscover and to set forth once more the authentic reality of the Christian faith, which is not simply a set of propositions to be accepted with intellectual assent. Rather, faith is a lived knowledge of Christ, a living remembrance of his commandments, and a truth to be lived out. A word, in any event, is not truly received until it passes into action, until it is put into practice. Faith is a decision involving one's whole existence. It is an encounter, a dialogue, a communion of love and of life between the believer and Jesus Christ, the Way, and the Truth, and the Life (cf. $J n$ 14:6). ${ }^{25}$

\footnotetext{
${ }^{24}$ VS 88.

${ }^{25}$ VS 88.
} 
przez normy moralne, które zakazują bez wyjątku dokonywania czynów wewnętrznie złych" ${ }^{32}$. Męczeństwo w perspektywie dyskusji relatywizujących normy moralne, poprzez ich „uzasadnianie” mocą kreatywnego sumienia ukierunkowanego na słuszność czynów i wspierającego się niezachwianym wyborem podstawowym, męczeństwo w tej perspektywie zyskuje swoją unikalną wartość. Papież wskazuje, że „pomaga uniknąć - i to nie tylko w społeczności cywilnej, ale także wewnątrz samych wspólnot kościelnych - najgroźniejszego zatarcia granicy między dobrem a złem, co uniemożliwia budowę i zachowanie porządku moralnego jednostek i społeczności ${ }^{33}$.

Trzeba zauważyć, iż męczeństwo - jako szczy towe potwierdzenie związku moralności i wiary, wyrażone w czynie - świadectwie jest zarazem potwierdzeniem świętości prawa Bożego, jak i nierozdzielnie z tym związanej „,nietykalności osobowej godności człowieka, stworzonego na obraz i podobieństwo Boga" ${ }^{34}$. Pozwala też zrozumieć, że najbardziej dobitnym wyrazem bycia człowiekiem jest fundamentalny temat „bycia w Chrystusie” lub „nowej egzystencji w Chrystusie".

Temat egzystencji człowieka w Chrystusie (,bycia w Chrystusie") ma szczególne znaczenie dla teologii moralnej, stanowi wręcz zagadnienie usytuowane w centrum rozważań antropologicznych. Chrystocentryzm antropologiczny jest zarazem kluczem interpretacyjnym rozważań „Veritatis splendor”. Jak bowiem zauważa Autor encykliki, to właśnie „Chrystus objawia przede wszystkim, że warunkiem autentycznej wolności jest szczere i otwarte uznanie prawdy: «poznacie prawdę, a prawda was wyzwoli» $(\mathrm{J} 8,32)^{35}$. To prawda pozwala zachować wolność wobec władzy i daje moc, by przyjąc męczeństwo" ${ }^{36}$. Kolejny wymiar chrystocentryzmu w antropologii pozwala dostrzec, że „Jezus objawia ponadto - i to samym

\footnotetext{
32 VS 90.

33 VS 93.

34 VS 92.

35 Cfr. RH 12.

36 VS 87.
} 
Karol K. Wojtyla, as a member of the Council, believes that the integration of faith and morality is a central and priority theme. Breaking this link means blocking the dynamism of faith, which, by its very nature, manages to permeate the whole person. Faith, according to the Council's decisions, 'throws a new light on everything, manifests God's design for man's total vocation, and thus directs the mind to solutions which are fully human. ${ }^{26}$ The integration of faith and morals is the fullest expression of integration and the constitution of man. „In other words, there is no such thing as the man and the Christian as separate entities; the Christian is the mysterious fulfilment of man." ${ }^{27}$ Such an approach does not imply that humanity is attributed solely to Christians, nor does it recognise the axiological superiority of Christians over non-Christians. Neither should the claim that there is no separation between Christian and human beings be interpreted in the sense that what is human is directly Christian. It is therefore possible, from a negative point of view, to see that the integration thus understood does not include either an extreme understanding of moral autonomy or a radical expression of , anonymous Christianity'. ${ }^{28}$ However, the need to integrate faith and morality must be seen as a special path that is an initiative of God. This is the way to bring man into communion with the person of God through Jesus Christ. The Church mediates on such a path towards communion.

The discovery of the content of faith implies the duty of witness.

„Faith also possesses a moral content. It gives rise to and calls for a consistent life commitment; it entails and brings to perfection the acceptance and observance of God's commandments. (...) Through the moral life,

26 Gaudium et spes 11.

27 Buttiglione, R. (1996) The Thought of the Man Who Became Pope John Paul II, translated by Paolo Guietti and Francesca Murphy, William B. Eerdmans Publishing Company, Cambridge, U.K. 211.

${ }^{28}$ Cf. ibidem, 211-220. 
swoim życiem, a nie tylko słowami - że wolność urzeczywistnia się przez mitość, to znaczy przez dar z siebie" ${ }^{37}$. Pozwala to ostatecznie stwierdzić, że „Jezus jest zatem żywą i osobową syntezą doskonałej wolności w całkowitym posłuszeństwie woli Ojca. Jego ukrzyżowane ciało to pełne objawienie nierozerwalnej więzi między wolnością a prawdą, zaś Jego powstanie z martwych to najwyższe świadectwo płodności i zbawczej mocy wolności przeżywanej w prawdzie"38.

Dostrzegając walor tego wymiaru antropologicznego, należy podkreślić, że jest on jedną z najbardziej czytelnych linii kontynuacji myśli teologicznej Soboru Watykańskiego II w nauczaniu Jana Pawła II. Warto, tytułem przykładu, zestawić dwa niezwykle charakterystyczne w tym względzie teksty:

„Tajemnica człowieka wyjaśnia się naprawdę dopiero w tajemnicy Słowa Wcielonego. Albowiem Adam, pierwszy człowiek był figurą przyszłego, mianowicie Chrystusa Pana. Chrystus, nowy Adam, już w samym objawieniu tajemnicy Ojca i Jego miłości objawia w pełni człowieka samemu człowiekowi i okazuje mu najwyższe jego powołanie. Nic więc dziwnego, że w Nim wyżej wspomniane prawdy znajdują swoje źródło i szczyt.

Ten, który jest «obrazem Boga niewidzialnego» (Kol 1, 15), jest człowiekiem doskonałym, który przywróci synom Adama podobieństwo Boże, zniekształcone od czasu pierwszego grzechu. Skoro w nim przybrana natura nie ulega zniszczeniu, tym samym została ona wyniesiona również w nas do wysokiej godności. Albowiem On, Syn Boży, przez wcielenie swoje zjednoczył się jakoś z każdym człowiekiem. Ludzkimi rękoma pracował, ludzkim myślał umysłem. ludzką działał wolą, ludzkim sercem kochał, urodzony z Maryi Dziewicy, stał się prawdziwie jednym z nas, we wszystkim do nas podobny oprócz grzechu.

Niewinny Baranek krwią swoją dobrowolnie wylaną wysłużył nam życie i w Nim Bóg pojednał nas ze sobą i między nami samymi oraz wyrwał z niewoli szatana i grzechu, tak że każdy z nas może

\footnotetext{
37 VS 87.
}

38 VS 87. 
faith becomes „,confession”, not only before God but also before men: it becomes witness. ${ }^{29}$

John Paul II, with his predicament, also confirmed by his ministry of beatification and canonisation, continues this reflection on the special bond of faith and witness, focused in martyrdom.

„The relationship between faith and morality shines forth with all its brilliance in the unconditional respect due to the insistent demands of the personal dignity of every man, demands protected by those moral norms which prohibit without exception actions which are intrinsically evil. ${ }^{30}$

Martyrdom in the perspective of discussions relativizing moral norms, by 'justifying' them with the power of a creative conscience directed at the rightness of acts and supported by unwavering fundamental choices, the martyrdom in this perspective gains its unique value. The Pope points out:

'[it ] makes an extraordinarily valuable contribution to warding off, in civil society and within the ecclesial communities themselves, a headlong plunge into the most dangerous crisis which can afflict man: the confusion between good and evil, which makes it impossible to build up and to preserve the moral order of individuals and communities' ${ }^{31}$.

It should be noted that martyrdom, as the culmination of the link between morality and faith, expressed in deed, is both a confirmation of the holiness of God's law and "the inviolability of the personal

\footnotetext{
29 VS 89.

30 VS 90

31 VS 93.
} 
wraz z Apostołem powiedzieć: Syn Boży «umiłował mnie i wydał samego siebie za mnie» (Gal 2, 20). Cierpiąc nie tylko dał przykład, byśmy szli w Jego ślady, lecz i otworzył nam nową drogę, którą jeśli idziemy, życie i śmierć doznają uświęcenia i nabierają nowego sensu.

Chrześcijanin zaś stawszy się podobnym do obrazu Syna, który jest Pierworodnym między wielu braćmi, otrzymuje «pierwociny Ducha» (Rz 8, 23), które czynią go zdolnym do wypełniania nowego prawa miłości. Przez tego Ducha, będącego «zadatkiem dziedzictwa» (Ef 1, 14), cały człowiek wewnętrznie się odnawia aż do «odkupienia ciała» $(\mathrm{Rz} 8,23)$. Bo «jeśli Duch tego, który wzbudził z martwych Jezusa Chrystusa, przebywa w was, ten, który z martwych wzbudził Jezusa Chrystusa, ożywi śmiertelne ciała wasze Duchem swym w was przebywającym» $(\mathrm{Rz} 8,11)$. Chrześcijanina przynagla z pewnością potrzeba i obowiązek walki ze złem wśród wielu utrapień, nie wyłączając śmierci, lecz włączony w tajemnicę paschalną, upodobniony do śmierci Chrystusa, podąży umocniony nadzieją ku zmartwychwstaniu" 39 .

Drugi tekst zamieszczony został w encyklice Jana Pawła II „Redemptor hominis". W numerze 10 dokumentu zatytułowanym „Ludzki wymiar Tajemnicy Odkupienia” znajdują się między innymi następujące słowa:

„Człowiek nie może żyć bez miłości. Człowiek pozostaje dla siebie istotą niezrozumiałą, jego życie jest pozbawione sensu, jeśli nie objawi mu się Miłość, jeśli nie spotka się z Miłością, jeśli jej nie dotknie i nie uczyni w jakiś sposób swoją, jeśli nie znajdzie w niej żywego uczestnictwa. I dlatego właśnie ChrystusOdkupiciel, jak to już zostało powiedziane, «objawia w pełni człowieka samemu człowiekowi». To jest ów jeśli tak wolno się wyrazić ludzki wymiar Tajemnicy Odkupienia. Człowiek odnajduje w nim swoją właściwą wielkość, godność i wartość swego człowieczeństwa. Człowiek zostaje w Tajemnicy Odkupienia na nowo potwierdzony, niejako wypowiedziany na nowo. Stworzony na nowo! «Nie ma już Żyda ani poganina, nie ma już niewolnika ani człowieka wolnego, nie ma już mężczyzny

\footnotetext{
${ }^{39} \mathrm{KDK} 22$.
} 
dignity of man, created in God's image and likeness" ${ }^{\prime 32}$. It leads to the understanding that the most striking expression of being human is the fundamental theme of ,being in Christ” or ,a new existence in Christ".

The topic of human existence in Christ (,being in Christ”) is of particular importance for moral theology, and is even at the centre of anthropological considerations. Anthropological Christocentrism is at the same time the interpretation key to Veritatis splendor deliberations. As the author of the encyclical notes:

„Christ reveals, first and foremost, that the frank and open acceptance of truth is the condition for authentic freedom: „You will know the truth, and the truth will set you free $(J n 8: 32)^{33}$. This is truth which sets one free in the face of worldly power and which gives the strength to endure martyrdom." 34

Another dimension of Christocentrism in anthropology is that „Furthermore, Jesus reveals by his whole life, and not only by his words, that freedom is acquired in love, that is, in the gift of self." 35 Thus, it can finally be concluded that:

„Jesus, then, is the living, personal summation of perfect freedom in total obedience to the will of God. His crucified flesh fully reveals the unbreakable bond between freedom and truth, just as his Resurrection from the dead is the supreme exaltation of the fruitfulness and saving power of a freedom lived out in truth." ${ }^{36}$

\footnotetext{
32 VS 92.

$33 \mathrm{RH} 12$.

${ }^{34}$ VS 87.

${ }^{35}$ VS 87.

36 VS 87.
} 
ani kobiety, wszyscy bowiem jesteście kimś jednym w Chrystusie Jezusie». Człowiek, który chce zrozumieć siebie do końca nie wedle jakichś tylko doraźnych, częściowych, czasem powierzchownych, a nawet pozornych kryteriów i miar swojej własnej istoty musi ze swoim niepokojem, niepewnością, a także słabością i grzesznością, ze swoim życiem i śmiercią, przybliżyć się do Chrystusa. Musi niejako w Niego wejść z sobą samym, musi sobie «przyswoić», zasymilować całą rzeczywistość Wcielenia i Odkupienia, aby siebie odnaleźć. Jeśli dokona się w człowieku ów dogłębny proces, wówczas owocuje on nie tylko uwielbieniem Boga, ale także głębokim zdumieniem nad sobą samym. Jakąż wartość musi mieć w oczach Stwórcy człowiek, skoro zasłużył na takiego i tak potężnego «Odkupiciela», skoro Bóg «Syna swego Jednorodzonego dał», ażeby on, człowiek, «nie zginął, ale miał życie wieczne».

Właśnie owo głębokie zdumienie wobec wartości i godności człowieka nazywa się Ewangelią, czyli Dobrą Nowiną. Nazywa się też chrześcijaństwem. Stanowi o posłannictwie Kościoła w świecie również, a może nawet szczególnie «W świecie współczesnym»" ${ }^{\star 40}$.

Przytoczony fragment encykliki papieskiej - programowego dokumentu pontyfikatu Jana Pawła prowokuje wręcz do najbardziej fundamentalnego pytania antropologicznego: skoro bowiem „człowiek pozostaje dla siebie istotą niezrozumiałą, jeśli mu się nie objawi miłość" to trzeba postawić pytanie - kim jest człowiek? W świetle „Redemptor hominis” staje się już sprawą jasną, to, co zostanie także potwierdzone wyraźnie w „Veritatis splendor”, że człowiek jawi się w papieskiej myśli jako samorządny podmiot. Znaczy to, że występuje jako centrum świadomych i wolnych, związanych poprzez prawdę działań. Można zauważyć w takim razie, że ten akt samoidentyfikacji nie odwołuje się do miłości - czy jednak istotnie? By odpowiedzieć na to pytanie, należy zauważyć, za Janem Pawłem II, że prawda, wiążąca wolność działania ludzkiego dana jest osobie przez sąd zwany sumieniem. Owo związanie dokonuje się wyłącznie mocą tego aktu, tak że „człowiek jako podmiot sumienia wiąże się prawdą swego

40 RH 10. 
While recognising the value of this anthropological dimension, it should be stressed that it is one of the most clear lines of continuation of the theological thought of the Second Vatican Council in the teaching of John Paul II. It is worthwhile, by way of example, to juxtapose two texts that are extremely characteristic in this respect:

„The truth is that only in the mystery of the incarnate Word does the mystery of man take on light. For Adam, the first man, was a figure of Him Who was to come,(20) namely Christ the Lord. Christ, the final Adam, by the revelation of the mystery of the Father and His love, fully reveals man to man himself and makes his supreme calling clear. It is not surprising, then, that in Him all the aforementioned truths find their root and attain their crown.

He Who is ,the image of the invisible God" (Col. 1:15), is Himself the perfect man. To the sons of Adam He restores the divine likeness which had been disfigured from the first sin onward. Since human nature as $\mathrm{He}$ assumed it was not annulled, by that very fact it has been raised up to a divine dignity in our respect too. For by His incarnation the Son of God has united Himself in some fashion with every man. He worked with human hands, He thought with a human mind, acted by human choice and loved with a human heart. Born of the Virgin Mary, He has truly been made one of us, like us in all things except sin. As an innocent lamb He merited for us life by the free shedding of His own blood. In Him God reconciled us to Himself and among ourselves; from bondage to the devil and sin He delivered us, so that each one of us can say with the Apostle: The Son of God „loved me and gave Himself up for me" (Gal. 2:20). By suffering for us He not only provided us with an example for our imitation, He blazed a trail, and if we follow it, life and death are made holy and take on a new meaning. 
sądu"41. To właśnie ten fenomen ludzkiego bytowania odsłania się dogłębnie w czynie - ulubionym miejscu analizy fenomenu człowieka w myśli Karola K. Wojtyły - Jana Pawła II.

\section{CZYN JAKO OBSZAR ROZPOZNAWANIA GODNOŚCI OSOBY}

Podstawowa refleksja nad antropologią teologiczną enuncjacji papieskich wskazuje, że człowiek zarówno w „Redemptor hominis”, jak i w „Veritatis splendor” jawi się nade wszystko jako samorządny podmiot działania, czyli jako centrum świadomych i wolnych, związanych poprzez prawdę działań. „Sam człowiek został powierzony własnej trosce i odpowiedzialności. Bóg pozostawił go «w ręku rady jego» (cfr. Syr 15, 14), aby szukał swego Stwórcy i dobrowolnie dochodził do doskonałości. Dochodzić - znaczy własnym wysitkiem budować w sobie tę doskonatość. Istotnie, podobnie jak rządząc światem człowiek kształtuje go wedle własnego rozumienia i woli, tak też spełniając czyny moralnie dobre potwierdza, rozwija i umacnia w sobie podobieństwo do Boga"42.

Wskazany akt samoidentyfikacji - poprzez odniesienie do świadomych, wolnych i ,prawdziwych” działań faktycznie nie odwołuje się do miłości. Wydaje się to zatem przeczyć stwierdzeniu antropologicznemu z „Redemptor hominis”, iż miłość jest wartością konstytutywną i wręcz definiującą osobę ludzką. Jednakże należy, z całą wnikliwością spojrzeć na dynamizm relacji świadomości, wolności i owego związania działań poprzez prawdę. Prawda, wiążąca wolność działania ludzkiego dana jest osobie przez sąd zwany sumieniem. Związanie dokonuje się wyłącznie mocą tego aktu, tak iż „,człowiek jako podmiot sumienia wiąże się prawdą swego sądu"43. Jan Paweł II

${ }^{41}$ T. Styczeń, Miłość a sens życia. Nad encyklika Jana Pawła II „Redemptor hominis", [w:] Jan Paweł II, Redemptor hominis. Tekst i komentarze, Lublin 1982, 91.

42 VS 39

${ }^{43}$ T. Styczeń, op. cit., 91. 
The Christian man, conformed to the likeness of that Son Who is the firstborn of many brothers, received ,the first-fruits of the Spirit" (Rom. 8:23) by which he becomes capable of discharging the new law of love. Through this Spirit, who is „the pledge of our inheritance” (Eph. $1: 14)$, the whole man is renewed from within, even to the achievement of "the redemption of the body” (Rom. 8:23): „If the Spirit of him who raised Jesus from the death dwells in you, then he who raised Jesus Christ from the dead will also bring to life your mortal bodies because of his Spirit who dwells in you" (Rom. 8:11). Pressing upon the Christian to be sure, are the need and the duty to battle against evil through manifold tribulations and even to suffer death. But, linked with the paschal mystery and patterned on the dying Christ, he will hasten forward to resurrection in the strength which comes from hope." ${ }^{37}$

The latter text is included in John Paul II's encyclical Redemptor hominis. In number 10 of the document entitled „The Human Dimension of the Mystery of the Redemption" one can find, among others, the following words:

„Man cannot live without love. He remains a being that is incomprehensible for himself, his life is senseless, if love is not revealed to him, if he does not encounter love, if he does not experience it and make it his own, if he does not participate intimately in it. This, as has already been said, is why Christ the Redeemer ,fully reveals man to himself". If we may use the expression, this is the human dimension of the mystery of the Redemption. In this dimension man finds again the greatness, dignity and value that belong to his humanity. In the mystery of the Redemption man becomes newly ,expressed” and,

${ }^{37}$ Gaudium et Spes 22. 
w „Veritatis splendor” przytacza kontestujące opinie teologiczne, które występowały i występują przeciw deprecjacji sumienia: „Według opinii niektórych teologów rola sumienia została sprowadzona, przynajmniej w pewnym okresie przeszłości, jedynie do stosowania ogólnych norm moralnych w konkretnych sytuacjach ludzkiego życia. Jednakże normy te - twierdzą owi teologowie - nie są w stanie ogarnąć i uwzględnić całej niepowtarzalnej specyfiki wszystkich konkretnych czynów ludzkich; mogą co prawda dopomóc w pewnej mierze w poprawnej ocenie danej sytuacji, nie mogą jednak zastąpić człowieka w podjęciu osobistej decyzji o tym, jak powinien postąpić w konkretnych przypadkach" ${ }^{\text {"44 }}$. Tego typu kontestacja staje u podstaw " «kreatywnego» charakteru sumienia" ${ }^{" 45}$. Papież zauważa wszakże, że niezależnie od intencji proklamujących zwiększenie odpowiedzialności moralnej i podkreślenie waloru personalistycznego w moralności chrześcijańskiej, tego typu ujęcie zagraża „samej tożsamości sumienia w jego relacji do wolności człowieka i prawa Bożego"46.

Problemem, który w tym miejscu się pojawia jest zagadnienie właściwego rozumienia autonomii moralnej człowieka. Dla Ojca św. kluczem interpretacji autonomii na miarę autentycznej godności osoby ludzkiej jest prawda, konkretniej zaś prawo moralne. „Prawdziwa autonomia moralna człowieka nie oznacza bynajmniej odrzucenia, ale właśnie przyjęcie prawa moralnego, Bożego przykazania: «Pan Bóg dał człowiekowi taki rozkaz» (Rdz 2, 16). Wolność człowieka i prawo Boże spotykaja się i sa powotane, aby się wzajemnie przenikać, czego wyrazem jest dobrowolne posłuszeństwo człowieka wobec Boga oraz bezinteresowna dobroć Boga wobec człowieka" ${ }^{\text {"77 }}$.

To właśnie w uznaniu tej zależności, która ma charakter wzajemnego przenikania, kryje się właściwa człowiekowi autonomia lub przynajmniej warunek konstytutywny i niezbędny tej samorządności. Jako istota racjonalna człowiek nie wyrzeka się swej racjonalności.

\footnotetext{
44 VS 55.

45 Ibidem.

46 VS 40.

47 VS 41.
} 
in a way, is newly created. He is newly created! „There is neither Jew nor Greek, there is neither slave nor free, there is neither male nor female; for you are all one in Christ Jesus"64. The man who wishes to understand himself thoroughly-and not just in accordance with immediate, partial, often superficial, and even illusory standards and measures of his being-he must with his unrest, uncertainty and even his weakness and sinfulness, with his life and death, draw near to Christ. He must, so to speak, enter into him with all his own self, he must „appropriate" and assimilate the whole of the reality of the Incarnation and Redemption in order to find himself. If this profound process takes place within him, he then bears fruit not only of adoration of God but also of deep wonder at himself. How precious must man be in the eyes of the Creator, if he ,gained so great a Redeemer" 65 , and if God, ,gave his only Son ,in order that man , should not perish but have eternal life" 66 .

In reality, the name for that deep amazement at man's worth and dignity is the Gospel, that is to say: the Good News. It is also called Christianity. This amazement determines the Church's mission in the world and, perhaps even more so, «in the modern world «"38.

This fragment of the papal encyclical, the programme document of John Paul's pontificate, provokes even the most fundamental anthropological question: since, man remains a creature incomprehensible to himself, if love is not revealed to him', the question must be asked - who is man? In the light of Redemptor hominis, the fact that man appears in papal thought as a self-governing subject is already becoming clear, which will also be confirmed clearly in Veritatis splendor. This means that he acts as a centre of conscious and free action, bound by the truth. One can see, then, that

${ }^{38} \mathrm{RH} 10$. 
„Stąd nie jest w stanie uznać danego sądu za swój akt inaczej jak tylko wówczas, gdy aktem tym stwierdza i wyraża swe uznanie, swą asercję, dla niezależnej od niego obiektywnej prawdy, gdy w swoim akcie sądu widzi - i umie zidentyfikować - akt poznania"48. To właśnie decyduje o tym, że dany akt jest aktem tej oto osoby i że pozwala na samoidentyfikację osoby. „Autentyczne samorządzenie, czyli poddawanie się rzeczywistej autonomii, jest więc dla człowieka możliwe tylko poprzez poddawanie się prawdzie swego sądu, nigdy zaś poprzez poddawanie sobie prawdy swego sądu"49. Trzeba wyraźnie zauważyć, że poddanie prawdy sądu sobie staje się w konsekwencji aktem samopoddania się w niewolę błędu (jest to zatem przykład i przejaw zniewolenia przez samozniewolenie).

Kwestia oceny autonomii człowieka nie może być, zdaniem Jana Pawła II, rozpatrywana w świetle abstrakcyjnej antropologii. Właściwym miejscem etycznego i moralnego odkrycia prawdy o człowieku nie jest bowiem ,wolność fundamentalna” czy „sumienie kreatywne”. Zarówno wolność, jak i sumienie zyskują swoją weryfikację w czynie ludzkim. Tak bardzo dobitnie podkreślał to już Karol K. Wojtyła. „Transcendencja osoby w czynie to nie tylko samozależność, zależność od własnego «ja». Wchodzi w nią również moment zależności od prawdy -i moment ten ostatecznie kształtuje wolność. Nie realizuje się ona bowiem przez podporządkowanie sobie prawdy, ale przez podporządkowanie się prawdzie" ${ }^{50}$.

Wydaje się, że nie sposób oderwać tych analiz etycznych od tego, co można nazwać stylem i duchem myślenia Autora encykliki „Veritatis splendor”. Wystarczy w tym miejscu przywołać choćby fragment dokumentu: „Dzięki Bożemu Objawieniu i dzięki wierze chrześcijanin poznaje «nowość», jaka odznacza się moralność jego czynów: mają one wyrażać jego wierność - lub niewierność - wobec tej godności i powołania, które zostały mu dane przez łaskę: w Jezusie Chrystusie i w Jego Duchu chrześcijanin jest «nowym stworzeniem»,

48 T. Styczeń, op. cit., 91.

49 Ibidem.

${ }^{50}$ K. Wojtyła, Osoba i czyn, Kraków 1969, 162. 
this act of self-identification does not refer to love - or does it? To answer this question, it should be noted, following John Paul II, that truth, the binding freedom of human action, is given to a person by a court called conscience. This binding is made exclusively by virtue of this act, so that, man as a subject of conscience is bound by the truth of his judgement. ${ }^{39}$ It is this very phenomenon of human existence that is revealed profoundly in the act - the favourite place of analysis of the human phenomenon in the thought of Karol Wojtyla - John Paul II.

\section{ACT AS AN AREA OF RECOGNITION OF A PERSON'S DIGNITY}

The basic reflection on the theological anthropology of papal enunciations indicates that man, both in Redemptor hominis and Veritatis splendor, appears above all as a self-governing subject of action, that is, as a centre of conscious and free action, bound by the truth.

„(...) man himself has been entrusted to his own care and responsibility. God left man, in the power of his own counsel" (Sir 15:14), that he might seek his Creator and freely attain perfection. Attaining such perfection means personally building up that perfection in himself. Indeed, just as man in exercising his dominion over the world shapes it in accordance with his own intelligence and will, so too in performing morally good acts, man strengthens, develops and consolidates within himself his likeness to God." ${ }^{40}$

This act of self-identification - by reference to conscious, free and „real” actions - does not actually refer to love. It seems, therefore, to

\footnotetext{
39 Styczeń, T. (1982) Miłość a sens życia. Nad encyklika Jana Pawła II „, Redemptor hominis", [in:] Jan Paweł II, Redemptor hominis. Tekst i komentarze, Lublin, 91.

${ }^{40}$ VS 39.
} 
synem Bożym, a poprzez swoje czyny objawia swe podobieństwo lub niepodobieństwo do obrazu Syna - pierworodnego między wielu braćmi (cfr. Rz 8, 29), okazuje w życiu wierność lub niewierność darowi Ducha Świętego i otwiera się lub zamyka na życie wieczne, na komunię wizji uszczęśliwiającej, miłości i szczęśliwości z Bogiem Ojcem, Synem i Duchem Świętym ${ }^{51}$. (...)

W tym sensie życie moralne ma charakter głęboko «teleologiczny», ponieważ polega na świadomym przyporządkowaniu ludzkich czynów Bogu - najwyższemu dobru i ostatecznemu celowi (telos) człowieka. (...) Ale to przyporządkowanie czynów ostatecznemu celowi to nie wymiar subiektywny, zależny wyłącznie od intencji. Zakłada ono, że czyny te same w sobie mogą zostać przyporządkowane owemu celowi dzięki swej zgodności z autentycznym dobrem moralnym człowieka, chronionym przez przykazania" 52 .

Jeszcze bardziej wymowny tekst wskazujący na konieczność odczytywania antropologii w ścisłej łączności z moralnością czynów znajduje się w innym miejscu: „w zagadnieniu moralnej jakości ludzkich czynów, a zwłaszcza w problemie istnienia czynów wewnętrznie złych koncentruje się w pewnym sensie sam problem człowieka, prawdy o nim oraz konsekwencji moralnych, jakie z niej wypływają"53.

Stanowisko Jana Pawła, z oczywistych względów, bardzo wyraźnie przypomina wnioski, do których dochodziła etyczna myśl Karola K. Wojtyły. Trzeba raz jeszcze nadmienić, że myśl ta wyrastała w obszarze dyskusji, w której jedną ze stron były refleksje wskazujące na wolę mocy jako jeden z zasadniczych wyznaczników do wyjaśnienia

${ }^{51}$ W Konstytucji duszpasterskiej o Kościele w świecie współczesnym Sobór Watykański II stwierdza jednoznacznie: „Dotyczy to nie tylko wiernych chrześcijan, ale także wszystkich ludzi dobrej woli, w których sercu działa w sposób niewidzialny łaska. Skoro bowiem za wszystkich umarł Chrystus i skoro ostateczne powołanie człowieka jest rzeczywiście jedno, a mianowicie Boskie, to musimy uznać, że Duch Święty wszystkim ofiaruje możliwość dojścia w sposób Bogu wiadomy do uczestnictwa w tej paschalnej tajemnicy". Gaudium et spes, 22.

52 VS 73.

53 VS 83. 
contradict the anthropological statement of Redemptor hominis that love is a constitutive and even defining value of the human person. However, the dynamism of the relationship of consciousness, freedom and the binding of actions through the truth must be looked at with all due care. Truth, the binding freedom of human action, is given to a person by a court called conscience. Binding is made only by the power of this act, so that ,man as a subject of conscience is bound by the truth of his judgment'. ${ }^{41}$ In Veritatis splendor, John Paul II quotes the opposing theological opinions that go against the depreciation of conscience:

\begin{abstract}
„According to the opinion of some theologians, the function of conscience had been reduced, at least at a certain period in the past, to a simple application of general moral norms to individual cases in the life of the person. But those norms, they continue, cannot be expected to foresee and to respect all the individual concrete acts of the person in all their uniqueness and particularity. While such norms might somehow be useful for a correct assessment of the situation, they cannot replace the individual personal decision on how to act in particular cases." ${ }^{42}$
\end{abstract}

This type of contestation underlies the ,«creative » character of conscience" ${ }^{\prime 43}$. After all, the Pope notes that, regardless of the intentions to proclaim increasing moral responsibility and emphasising the personalistic value of Christian morality, such an approach threatens ,the very identity of conscience in its relationship to human freedom and God's law'. ${ }^{44}$

\footnotetext{
${ }^{41}$ Styczeń, T. op. cit., 91.

42 VS 55

${ }^{43}$ Ibidem.

44 VS 40
} 
rzeczywistości człowieka. Raz jeszcze wypada powtórzyć hasłowym wywołaniem to wszystko, co uczyniła w tym zakresie filozofia nowożytna, poprzez wzbogacenie filozofii woli (koncepcja dobrej woli-Kanta; woli życia - Schopenhauera; woli mocy - Nietzschego). Koncepcja Karola K. Wojtyły, jako głos w tej dyskusji wychodziła z analizy ludzkiego dynamizmu jako punkt wyjścia wolności. Zarazem to samo doświadczenie ludzkiego dynamizmu jest punktem wyjścia dla koncepcji samostanowienia. W tym doświadczeniu człowiek ujawnia się jako istnienie (byt) i jako podmiot działania (suppositum). Między istnieniem a działaniem istnieje ściśle określona relacja, którą tradycja wyrażała w formule - operari sequitur esse. Oznacza to, że dynamika bytu ludzkiego jest zależna przyczynowo od istnienia człowieka jako bardziej fundamentalnego. Więź między esse a operari ma swoje implikacje epistemologiczno-ontologiczne: konkretniej - operari ułatwia zrozumienie esse. Tak więc konkluzje etyczne filozofa - Autora „Osoby i czynu” wskazywały, że ,analiza dynamizmu ludzkiego jest kluczem do prawdy o człowieku jako podmiocie w znaczeniu metafizycznym i osobowym" 54 . Stąd też zarazem wyrastał postulat ukazania osoby nie tyle ,poza-zjawiskowo" co „poprzez-zjawiskowo” („transfenomenalnie”).

Fundamentalnym rozróżnieniem wskazywanym przez Autora „Osoby i czynu” było przywołanie tego, że dynamizm ludzki ma dwojaki charakter. $Z$ jednej strony istnieje tutaj jedność i całość, którą stanowi przestrzeń „dziania się”. Jest jednak też zróżnicowanie - doświadczenie, że coś się we mnie dzieje i paralelne do niego doświadczenie, określane sformułowaniem. „człowiek działa”. Jest to dzianie się w podmiocie i dzianie się podmiotu ${ }^{55}$.

${ }^{54}$ J. Galarowicz, Człowiek jest osoba. Podstawy antropologii filozoficznej Karola Wojtyly, Kraków 1994, 185; cfr. K. Wojtyła, Osoba: podmiot i wspólnota, RF 24:1976 z. 2, 9-11.

${ }^{55}$ Wydaje się, że rozróżnienia K. Wojtyły w jakiejś mierze korespondują z rozróżnieniem Ricoeura (tego, co chciane i tego, co nie chciane. Cfr. P. Ricoeur, Philosophie de la volonte'. I. Le Volontaire et l'involontaire, Paris 1950; M. Philibert, Paul Ricoeur, czyli wolność na miarę nadziei, Warszawa 1976, 43-61); 
The problem that arises here is that of a proper understanding of human moral autonomy. For the Holy Father, the key to interpreting autonomy in accordance with the authentic dignity of the human person is truth, and more specifically moral law.

„Man's genuine moral autonomy in no way means the rejection but rather the acceptance of the moral law, of God's command: „The Lord God gave this command to the man..." (Gen 2:16). Human freedom and God's law meet and are called to intersect, in the sense of man's free obedience to God and of God's completely gratuitous benevolence towards man." ${ }^{45}$

It is in recognition of this interdependence, which is a mutual interpenetration, that there is a person's own autonomy, or at least the constitutive and necessary condition of that autonomy. As a rational being, man does not renounce his rationality. ,Therefore, he is not able to consider a judgment as his act except when it states and expresses his appreciation, his assertion, for an objective truth independent of him, when in his act of judgment he sees - and can identify - an act of cognition". ${ }^{46}$ This is what determines that an act is an act of this person and that it allows for self-identification. ,Authentic selfruling, that is to say, submission to genuine autonomy, is therefore only possible for a human being by submitting oneself to the truth of one's court, and never by submitting the truth of one's court to oneself" ${ }^{47}$ It should be clearly noted that submitting the truth of the judgment to oneself is, as a consequence, an act of self-submission to the slavery of a mistake (it is therefore an example and a manifestation of enslavement through self-slavery).

The issue of assessing human autonomy cannot, according to John Paul II, be considered in the light of abstract anthropology. The proper

\footnotetext{
45 VS 41.

46 T. Styczeń, op. cit., 91.

47 Ibidem.
} 
Obydwa dynamizmy łączy to, że stanowią one akty zakorzenione w tym samym podmiocie (osobie ludzkiej). Różni je natomiast to, że są różne jakościowo (dzianie się - bierne, pati; czyn - aktywność, agere). Dzianie się jest niejako związane peryferyjnie z osobą, natomiast czyn występuje w samym centrum bytu ludzkiego. Można inaczej stwierdzić, że czyn jest związany z ,ja” bardziej ściśle niż ma to miejsce w przypadku dziania się ${ }^{56}$.

Także różny jest moment sprawczości - jest ona doświadczana tylko w czynie; w wypadku czynu - osoba jest źródłem esse i fieri czynu. Inaczej ujmując, jest źródłem świadomym tego, iż nim jest. „Spełniając czyn, doświadczam nie tylko tego, że źródło czynu znajduje się w obrębie tej całości - «ja» osobowym" "57. Stąd «ktoś» jest źródłem czynu, podczas, gdy «coś» jest źródłem dziania się. Bardzo ważnym jest przypomnienie Karola K. Wojtyły, iż czyn jest nie tylko własnością podmiotu, ale i źródłem odpowiedzialności. „Człowiek staje się «kimś» i «jakimś» nade wszystko przez swoje czyny, przez działanie świadome. [...] Człowiek przez swoje czyny, przez działanie świadome, staje się dobrym lub złym w znaczeniu moralnym" 58 . Taka teza nie oznacza oczywiście, że człowiek jest miarą wszechrzeczy, źródłem wartości i autokreatorem, lecz uznaje twórczy i odpowiedzialny współudział osoby ludzkiej w ostatecznym ukształtowaniu siebie.

Doświadczenie zawarte w czynie stawia osobę ludzką w obliczu transcendencji wobec działania, a zarazem dogłębnego uznania własnej immanencji. Trzeba bowiem zauważyć, że «ja» w stosunku do czynu jest nadrzędne, w odniesieniu do dziania jest podporządkowane dynamizmowi.

Owym dynamizmom odpowiadają w bycie ludzkim dwie struktury - „sprawczość i podmiotowość zdają się przecinać pole ludzkich

Guardiniego (cfr. R. Guardini, Wolność, łaska, los, Kraków 1995, 228-230) czy Krąpca (M.A. Krąpiec, Decyzja - bytem moralnym, RF 31:1983 z. 2, 47-56).

${ }_{56}$ Cfr. J.W. Gałkowski, Wprowadzenie, RF 28:1980 z. 2, 103-105.

57 J. Galarowicz, op. cit., 187.

${ }^{58}$ K. Wojtyła, Osoba..., op. cit., 125. 
place for the ethical and moral discovery of the truth about man is not „fundamental freedom” or „,creative conscience”. Both freedom and conscience gain their verification in a human act. It was emphasised so emphatically by Karol K. Wojtyla. „, The transcendence of the person in the action does not consist solely either in the ontological autonomy, or self-centred dependence on the ego. It includes also the indispensable and essential moment of reference to „truth," and it is this moment that ultimately determines freedom. For human freedom is not accomplished nor exercised in bypassing truth but, on the contrary, by the person's realization and surrender to truth." 48

It seems that it is impossible to separate these ethical analyses from what can be called the style and spirit of thinking of the author of the encyclical ,Veritatis splendor'. At this point, it is enough to cite just a fragment of the document:

„The Christian, thanks to God's Revelation and to faith, is aware of the "newness" which characterizes the morality of his actions: these actions are called to show either consistency or inconsistency with that dignity and vocation which have been bestowed on him by grace. In Jesus Christ and in his Spirit, the Christian is a ,new creation", a child of God; by his actions he shows his likeness or unlikeness to the image of the Son who is the first-born among many brethren (cf. Rom8:29), he lives out his fidelity or infidelity to the gift of the Spirit, and he opens or closes himself to eternal life, to the communion of vision, love and happiness with God the Father, Son and Holy Spirit." ${ }^{\prime 49}$

${ }^{48}$ K. Wojtyła, (1979) The Acting Person, D. Reidel Publishing Company, Dordrecht, Holland, 104-105.

49 In the Pastoral Constitution on the Church in the Modern World, the Second Vatican Council states explicitly: „All this holds true not only for Christians, but for all men of good will in whose hearts grace works in an unseen way. For, since Christ died for all men, and since the ultimate vocation of man is in fact one, and divine, we ought to believe that the Holy Spirit in a manner known only to God 
przeżyć na dwie do siebie niesprowadzalne dziedziny. Wraz z przeżyciami idą struktury. Struktura «człowiek działa» oraz struktura «coś się dzieje w człowieku» zdają się dzielić człowieka na jakby dwa światy”59. Obydwie struktury - „coś się dzieje w człowieku” i ,człowiek działa” - są zakorzenione w samym dynamicznym podmiocie i różnicują zarazem go na podmiotowość jako źródło działań (uczynnień) i sprawcę czynów.

Wyżej wymienione struktury rozdzielają pole fenomenologiczne doświadczenia, natomiast w polu metafizycznym się jednoczą. W takim kontekście osoba jest ich syntezą jako suppositum. Pozwala to stwierdzić, że człowiek bytuje podmiotowo, gdy jest metafizycznym podmiotem istnienia i dynamizmów oraz gdy przeżywa siebie jako podmiot. Warunkiem odsłonięcia ludzkiej podmiotowości jest analiza wszechstronna i całościowa ludzkiego dynamizmu i jego korzeni, ale podstawowe znaczenie posiada tutaj czyn: „świadome działanie człowieka, w którym wyraża się i konkretyzuje zarazem wolność właściwa osobie ludzkiej”60.

Tak więc, jakkolwiek człowiek jest ontologicznie, „z natury” osobą, to jednak faktyczne bycie osobą i przejawy podmiotowości (czyn) odsłaniają się na pewnym etapie rozwoju. To właśnie w doświadczeniu czynu staje się obecny moment wolności, w przeciwieństwie do tego, co się dzieje w człowieku. „Wnikając w integralną strukturę stawania się człowieka moralnie dobrym lub też moralnie złym dzięki jego czynom, czyli działaniom świadomym, odkrywamy w tej integralnej strukturze właściwy moment wolności. [...] wolność jest korzeniem stawania się człowieka dobrym lub złym poprzez czyny, jest korzeniem samego fieri ludzkiej moralności" ${ }^{\prime 61}$.

Subtelność analiz etycznych staje się, zdaniem Jana Pawła II, bezwzględnie bardziej przejrzysta, gdy człowiek zostanie objawiony sobie samemu w perspektywie chrystocentrycznej. Jest to jedyna perspektywa umożliwiająca człowiekowi wejście wgłąb tajemnicy

\footnotetext{
59 Ibidem, 93.

${ }^{60}$ K. Wojtyła, Osoba: podmiot..., op. cit., 10.

${ }^{61}$ K. Wojtyła, Osoba..., op. cit., 126.
} 
„Consequently the moral life has an essential ,teleological” character, since it consists in the deliberate ordering of human acts to God, the supreme good and ultimate end (telos) of man. (...) But this ordering to one's ultimate end is not something subjective, dependent solely upon one's intention. It presupposes that such acts are in themselves capable of being ordered to this end, insofar as they are in conformity with the authentic moral good of man, safeguarded by the commandments." ${ }^{, 50}$.

An even more significant text indicating the need to read anthropology in close connection with the morality of deeds says that ,in the question of the morality of human acts, and in particular the question of whether there exist intrinsically evil acts, we find ourselves faced with the question of man himself, of his truth and of the moral consequences flowing from that truth." ${ }^{51}$

For obvious reasons, the position of John Paul is very clearly reminiscent of the conclusions drawn from Karol K. Wojtyła's ethical thought. It should be mentioned once again that this thought arose in the area of discussion, in which one of the parties was a reflection indicating the will of power as one of the fundamental determinants for explaining human reality. Once again, it is appropriate to reiterate with a sloganlike call all that modern philosophy has done in this field, by enriching the philosophy of will (the concept of good will by Kant; the will of life by Schopenhauer; the will of power by Nietzsche). Karol K. Wojtyła's concept, as a voice in this discussion, came out of the analysis of human dynamism as a starting point for freedom. At the same time, the same experience of human dynamism is the starting point for the concept of self-determination. In this experience man reveals himself as an existence (being) and as a subject of

offers to every man the possibility of being associated with this paschal mystery". Gaudium et spes 22.

50 VS 73.

51 VS 83. 
trynitarnej jako klucza do zrozumienia misterium osoby ludzkiej ${ }^{62}$. Tak ujęta prawda o istnieniu człowieka oznacza konieczność wejścia w głębokości Boga, by dostrzec, czy też raczej „przekroczyć próg naszej własnej tajemnicy" ${ }^{\prime 3}$.

W tym kontekście można przytoczyć znane augustyńskie: „Noverim me" i "Noverim Te" i potraktować je jako centralne pytanie antropologii, które zarazem staje się pytaniem par excellance teologicznym, jako wewnętrzna logika sprawy człowieka. To właśnie teologia w prologu Ewangelii wg Jana przypomina, że „Boga nikt nigdy nie widział". Można to stwierdzenie potraktować jako wprowadzenie w zwiastowanie rozwiązania problemu człowieka, który znajduje się w tym samym tekście: „Lecz Jednorodzony Syn, który jest na łonie Ojca, objawił Go" $(\mathrm{J} 1,18)$. Chrystus jako ikona Ojca pozwala zrozumieć tajemnicę zarówno Boga, jak i człowieka (cfr. „Kto widzi mnie, widzi i Ojca” [J 14, 9]). Aby możliwe było to „ujrzeliśmy" konieczne były dwa inne wydarzenia określane w teologii hasłowo: Verbum caro oraz Deus homo. „Słowo Boże jest Słowem

${ }^{62}$ Cfr. interesującą analizę - medytację T. Stycznia w oparciu o rzeźbę w katedrze w Chartres: „Cała głębia trynitarnej nauki o stworzeniu człowieka zostaje tu [w rzeźbie z Chartres - PB] jednym rzutem unaoczniona postacią Stwórcy o twarzy Chrystusa. Rzeźbiarz [...] przemienia w obraz słowo objawienia wieszczące, że Stwórca zatrzymał się jakby u progu swej własnej tajemnicy przed powołaniem człowieka do istnienia, jakby musiał sam naprzód wejść w swą głębię dla wydobycia z jej dna decyzji, którą nieoczekiwanie wysłowi liczbą mnogą: «Uczyńmy człowieka na Nasz obraz, podobnego Nam" (Rdz 1, 26). [...] Zwrot [...] niedwuznacznie sugeruje, że stworzenie człowieka - widziane z Bożej niejako perspektywy - oznacza łaskawe wprowadzenie go przez Stwórcę do szczególnego uczestnictwa w tym samym życiu, które jest wyłączną własnością Boga, Jego życiem wewnętrznym, «istotowo Boską Komunią Osób». Żyć dla człowieka, to być z daru dopuszczonym w obręb - i mieć dzięki temu udział - w tej samej «Boskiej Komunii Osób»" T. Styczeń, Bóg Ojcem... Medytacja nad mniej znanym tytułem encykliki „Dives in misericordia". W: Jan Paweł II. Dives in misericordia. Tekst i komentarze. Red. S. Nagy, Lublin 1983 s. 85-86. Cfr. także: Jan Paweł II. Mężczyzną i niewiastą stworzył ich. Odkupienie ciała a sakramentalność małżeństwa. Libreria Editrice Vaticana 1986.

63 T. Styczeń, Bóg Ojcem, 86. 
action (suppositum). Between existence and action there is a strictly defined relationship, which tradition expressed in the formula operari sequitur esse. This means that the dynamics of human being is causally dependent on human existence as more fundamental. The relationship between esse and operari has its epistemological and ontological implications: more specifically, operari facilitates understanding esse. Thus, the ethical conclusions of the philosopher - the author of The Acting Person - indicated that ,the analysis of human dynamism is the key to the truth about man as a subject in the metaphysical and personal sense" ${ }^{52}$. Hence, there was also a postulate to show a person not so much „off-phenomenonically” but ,throughphenomenonically” (,transfenomenally”).

The fundamental distinction indicated by the author of The Acting Person was to recall the fact that human dynamism has a dual character. On the one hand, there is the unity and the entirety, which is the space of ,happening”. However, there is also a difference the experience that something is happening in me and a parallel experience to it, defined by the formulation. „man acts". It is the act in the subject and the act of the subject. ${ }^{53}$

What both dynamisms have in common is that they constitute acts rooted in the same subject (human person). What makes them different is that they are different in quality (happening - passive, pati; acting - activity, agere). Acting is in a way peripherally related to the person, while the act occurs in the very centre of human being.

52 Galarowicz, J. (1994) Człowiek jest osoba. Podstawy antropologii filozoficznej Karola Wojtyły, Kraków, 185; cf. Wojtyła, K. The Person: Subject and Community, RF 24:1976 z. 2, 9-11.

${ }^{53}$ It seems that Wojtyla's distinctions correspond, to some extent, to those of Ricoeura (the wanted and the unwanted). Cf. P. Ricoeur, Philosophie de la volonte'. I. Le Volontaire et l'involontaire, Paris 1950; Philibert, M. Paul Ricoeur, czyli wolność na miarę nadziei, Warsaw 1976, 43-61); Guardiniego (cf. Guardini, R. Wolność, łaska, los, Kraków 1995, 228-230) or Krąpiec (Krąpiec, M. A. Decyzja - bytem moralnym, RF 31:1983 z. 2, 47-56). 
Boga o Bogu dla Boga. Słowo Boże Wcielone jest Słowem Boga o Bogu dla ludzi. Jest oknem wystawowym Boga wśród ludzi. Słowo Boże o Bogu staje się dla człowieka oknem na Boga przez to, że człowiek jest w stanie w nie patrzeć i w nim Boga wypatrzyć. Słowo Boże staje się oknem na Boga również przez to, że w nim człowiek dostrzega także, dlaczego Bóg tak bardzo zabiega o postawienie mu Siebie przed oczy. [...]

Okno wystawowe Boga na Boga jest bowiem samo Bogiem mówi o sposobie bytowania Boga. Bóg działając objawia, kim jest! Osoba objawia się w swoim czynie. Zaœ actus personae to personae actus!"’64.

Odpowiedź na pytanie Cur Deus homo? jest najgłębszą odpowiedzią na pytanie kim jest Bóg dla człowieka i zarazem równie głębokim wyjaśnieniem kwestii - kim jest człowiek? (z racji głębi odpowiedzi na pytanie: kim jest człowiek dla Boga?). W takim świetle warto przytoczyć słowa Jana Pawła II: „Kościół przyniósł Polsce Chrystusa - to znaczy klucz do zrozumienie tej wielkiej i podstawowej rzeczywistości, jaką jest człowiek. Człowieka bowiem nie można do końca zrozumieć bez Chrystusa. A raczej: człowiek nie może sam siebie do końca zrozumieć bez Chrystusa. Nie może zrozumieć, ani kim jest, ani jaka jest jego właściwa godność, ani jakie jest jego powołanie i ostateczne przeznaczenie. Nie może tego wszystkiego zrozumieć bez Chrystusa" ${ }^{65}$.

To właśnie Chrystus odsłania całą głębię daru wybrania i powołania człowieka, ale i odsłania ciężar odpowiedzialności. Ten ciężar nakłada na człowieka jego własna wielkość, a dokładniej - Miłość Stwórcza z takim darem wybrania. Wybranie zatem staje się wezwaniem (cfr. amor meus pondus meum - miłość jest ciężarem, ale takim, który unosi niosącego ten ciężar).

Chrystus zatem, w którym Bóg objawia swoją miłość, potwierdza, że istotą człowieczeństwa, samą głębią prawdy o człowieku jest nie

\footnotetext{
${ }^{64}$ Ibidem, 87.

65 Jan Paweł II. [Homilia] na Placu Zwycięstwa. Warszawa 2.06.1979 r. W: Pielgrzymka Jana Pawła II do Polski. Poznań - Warszawa 1979, 22.
} 
It can be otherwise stated that the act is more closely related to the „I" than it is in the case of action. ${ }^{54}$

Also, the moment of activity is different - it is experienced only in deed; in the case of an act, the person is the source of the esse and fieri of the act. In other words, the person is a source aware of the fact that he or she is the act. „By acting, I experience not only that the source of the deed is within the entirety - the personal "self»". ${ }_{55}$ Hence ,someone' is the source of acting, while ,something' is the source of happening. What is very important is Karol K. Wojtyła's reminder that the act is not only the property of the subject, but also a source of responsibility.

„Human actions once performed do not vanish without trace: they leave their moral value, which constitutes an objective reality intrinsically cohesive with the person, and thus a reality also profoundly subjective. Being a person man is ,somebody" and being somebody he may be either good or bad. ${ }^{56}$

Such a thesis does not, of course, mean that man is a measure of all things, a source of values and a self-creator, but recognises the creative and responsible participation of the human person in the final self-forming.

The experience of an act puts the human person confronted with transcendence in the face of action and, at the same time, a profound recognition of his own immanence. It should be noted that the ,I' is superior to the act, and is subject to dynamism when it comes to action.

Two structures correspond to these dynamisms in human being:

${ }^{54}$ Cf. Gałkowski J.W., Wprowadzenie, RF 28:1980 z. 2, 103-105.

55 J. Galarowicz, op. cit., 187.

56 K. Wojtyła, The Acting..., op. cit., 102-103. 
tyle wolność, co miłość - bezinteresowny, wolny, darmowy i nieodwołalny dar z samego siebie. „Zwłaszcza $w$ Chrystusie ukrzyżowanym znajduje Kościół odpowiedź na nurtujące dziś tak wielu ludzi pytanie o to, czy posłuszeństwo wobec uniwersalnych i niezmiennych norm moralnych może wyrażać szacunek dla jedyności i niepowtarzalności każdej ludzkiej osoby i nie zagrażać jej wolności i godności. [...] Chrystus ukrzyżowany objawia autentyczny sens wolności, w petni go realizuje poprzez catkowity dar z siebie i powołuje swoich uczniów do udziału w tej samej wolności”' ${ }^{\prime}$.

Tak więc kontemplacja Chrystusa ukrzyżowanego oraz komunia z Nim stanowią główną drogę zmierzania Kościoła w kierunku zrozumienia istoty wolności, która jest darem z siebie w służbie Bogu i braciom. Oznacza to zarazem bezwzględnie maksymalizm moralności uczniów Jezusa ${ }^{67}$.

W Chrystusie, zwłaszcza zaś w Jego misterium paschalnym, objawia się samo centrum prawdy o człowieku jako obrazie Boga, a także nierozłącznie związanej z nią prawdy o nowym stworzeniu. Syntetycznie można wobec tego zauważyć, że chrześcijanin w perspektywie prymatu wolności w wizji antropologicznej, dopełnionej teologicznym tematem ,nowego stworzenia w Chrystusie” swój fakt bycia „nowym stworzeniem” zawdzięcza temu, że jest powołany do nadprzyrodzonej wspólnoty z Ojcem przez Syna w Duchu Świętym. Dokonuje się to „,nowe stworzenie” przez uczestnictwo w paschalnym misterium Chrystusa, a chrześcijanin ukształtowany na wzór Chrystusa Najwyższego Kapłana, żyje, aby oddawać chwałę Bogu, czy raczej aby „być chwałą Boga”. Uznanie antropologii zogniskowanej nie na wolności, ale na miłości, pozwala wreszcie zauważyć, że chrześcijanin posiada dziecięctwo Boże na wzór Chrystusa przez Ducha Świętego, a także, że jest wyzwolony z grzechu i śmierci. „Nowe stworzenie” wyraża również egzystencję w jej wymiarze nowej wspólnoty życia - uczeń Jezusa jest członkiem nowego Ludu

66 VS 85.

${ }^{67}$ Cfr. S. Mojek, Maksymalizm moralny, [w:] Veritatis splendor. Przestanie moralne Kościoła, red. B. Jurczyk, Lublin 1994, 124-126. 
„Efficacy and subjectiveness seem to split the field of human experiences into two mutually irreducible factors. Experiences are associated with structures. The structure of ,man acts” and the structure of ,something-happensin-man" seem to divide the human being as if they were two separate levels." ${ }^{57}$

Both structures, this is of „, something-happens-in-man ,, and of „, man acts , are rooted in the dynamic entity itself and at the same time differentiate it into subjectivity as a source of actions (deeds) and perpetrator of acts.

The aforementioned structures separate the phenomenological field of experience, while in the metaphysical field they unite. In such a context a person is their synthesis as suppositum. This allows us to state that a person is subjective when he or she is a metaphysical subject of existence and dynamism and when he or she experiences himself or herself as a subject. The condition for revealing human subjectivity is a comprehensive and holistic analysis of human dynamism and its roots, but the act is fundamental here: ,, conscious human activity, in which the freedom proper to the human person is simultaneously expressed and concretised". ${ }^{58}$

Thus, although man is ontologically, „by nature” a person, the actual being of a person and the manifestations of subjectivity (act) are revealed at a certain stage of development. It is in the experience of an act that the present moment of freedom becomes present, as opposed to what is happening in man.

„By penetrating the integral structure of becoming a morally good or morally evil person through his or her actions, that is, conscious actions, we discover the right moment of freedom in this integral structure. [...]

57 Ibidem, 51.

58 K. Wojtyła, The Person: Subject ..., op. cit., 10. 
Bożego (Kościoła), a także jest ukierunkowany na ostateczną pełnię w Chrystusie ${ }^{68}$.

Osobowy charakter człowieka jego racjonalność i możliwości wynikające z wolnej woli, siła transcendowania, możliwość stawiania (rozpoznawania) celu i jego realizacji wszystko to wyróżnia zdecydowanie człowieka spośród innych stworzeń. Nakłada też obowiązek formowania własnych postaw życiowych, adekwatnych do potencjału osobowego. Jest też znamieniem dojrzałości, gdyż człowiek dojrzały reflektuje nad sensem własnego życia, nad celem swoich wysiłków i zamierzeń. Dla człowieka religijnego sfera tego celu i jego autorstwo pozostają w ścisłym i bezpośrednim związku z Bogiem. Czytelnym stają się wówczas słowa św. Pawła: „Albowiem tych, których od wieków poznał, tych też przeznaczył na to, by się stali na wzór obrazu Jego Syna. (...) Tych zaś, których przeznaczył, tych też powołał, a których powołał tych też usprawiedliwił, obdarzył chwałą" (Rz 8, 2930).

Pismo święte, Tradycja Kościoła, jak i współczesne nauczanie Magisterium, włącznie z encykliką „Veritatis splendor”, nie pozostawiają wątpliwości co do tego, że kresem ludzkiego przeznaczenia jest sam Bóg i wspólnota osobowa z Nim. „Bóg bowiem stworzył nas, byśmy Go poznawali, służyli Mu, miłowali Go, i w ten sposób doszli do raju. Szczęście czyni nas «uczestnikami Boskiej natury» (2 P 1, 4) i życia wiecznego [cfr. J 17, 3]. Wraz z nim człowiek wchodzi do chwały Chrystusa [cfr. Rz 8, 18] i do radości życia trynitarnego"69. Charakter wielu wypowiedzi biblijnych jest przy tym tak dobitny, że mają one znamię świadectwa.

Słownictwo biblijne, a za nim terminologia innych świadectw, zwykło określać rzeczywistość trwałej wspólnoty z Bogiem w kategoriach „widzenia” (cfr. 1 Kor 13, 12; 1 J 3, 2; Ap 7, 916; 22,4). Jednak z danych Objawienia wynika jednoznacznie, że przeznaczenie człowieka do bezpośredniego oglądania Boga należy do sfery nadprzyrodzonej, to jest do poziomu, do którego tylko sam Bóg

${ }^{68}$ Cfr. VS 86-87.

${ }^{69}$ KKK 1721. 
freedom is the root of becoming good or bad by actions, it is the root of the very fieri of human morality. ${ }^{59}$

According to John Paul II, the subtlety of ethical analyses becomes absolutely more transparent when a person is revealed to himself in a Christocentric perspective. This is the only perspective that enables man to enter into the Trinitarian mystery as the key to understanding the mystery of the human person. ${ }^{60}$ The truth about the existence of man, expressed in that way, means that it is necessary to enter the depths of God in order to see, or rather ,cross the threshold of our own mystery, ${ }^{61}$

In this context, the famous Augustinian Noverim me and Noverim Te should be treated as the central question of anthropology, which at the same time becomes a question of par theological excellence, as the internal logic of the human case. It is the theology in the prologue of the Gospel according to John that reminds us that „,no one has ever seen God". This statement can be seen as an introduction to the

59 K. Wojtyła, The Person: Subject ..., op. cit., 126.

${ }^{60} \mathrm{Cf}$. an interesting analysis - meditation by T. Styczeń based on the sculpture in the Cathedral of Chartres: „The whole depth of Trinitarian science about the creation of man is here [in the sculpture of Chartres - PB] revealed at one glance by the figure of the Creator with the face of Christ. The sculptor [...] transforms into an image the word of revelation that announces that the Creator has come to a halt as if on the threshold of his own mystery before man's vocation to existence, as if he himself had to go forward into his depths in order to extract from its bottom a decision that he would unexpectedly send out in the plural: „Let us make man in our image, after our likness". (Gen 1,26)....] The phrase ... unambiguously suggests that the creation of man - as seen from God's perspective - means the gracious introduction of man by the Creator to a special participation in the same life, which is God's exclusive property, his inner life, „the essential Divine Communion of Persons". To live for man means to be allowed to participate in the same „Divine Communion of Persons", and thus to have a share in it. Styczeń, T. Bóg Ojcem... Meditation on the lesser known title of the encyclical „Dives in misericordia”. In: John Paul II. Dives in misericordia. Text and comments. Ed. Nagy, S. (1983 ) Lublin 85-86. Cf. also: John Paul II. Man and Woman He Created Them. A Theology of the Body and the Sacramentality of Marriage. Libreria Editrice Vaticana 1986.

${ }^{61}$ T. Styczeń, Bóg Ojcem, 86. 
może wynieść człowieka. Tak więc treść przeznaczenia jest w jak najbardziej ścisłym tego słowa znaczeniu nadprzyrodzona ${ }^{70}$.

Obiektywny finalizm ludzkiego życia w postaci trwałej wspólnoty z Bogiem nie wyczerpuje misterium przeznaczenia. Pozostaje przecież jeszcze aspekt subiektywny podmiotowy. Jest nim przede wszystkim miłość do Boga i udział w Jego miłości. Oznacza to, że chrześcijańska egzystencja jest ukierunkowana na miłość, która jest wartością najistotniejszą. Dodatkowo, przy tym zetknięciu się ludzkiej miłości z Bogiem, który jest Miłością dokonuje się całkowite wyniesienie ludzkiego bytu. Nie oznacza to zniweczenia naturalnej struktury bytowej osoby, ale nadanie zupełnie nowej relacji do rzeczywistości.

„Człowiek, osiągnąwszy kres swego przeznaczenia, staje się posiadaczem tego, czego domaga się cała jego istota. Odpadają odeń wszelkie doczesne pragnienia, a udziałem jego staje się pełnia osobowa, spokój i uciszenie wewnętrzne. Ten spoczynek w Bogu, rodzący radość i stan pełnego nasycenia, teologia określa posługując się terminem św. Tomasza jako szczęśliwość zbawczą (beatitudo). Objawienie wykazuje, że w planach Bożych jest ona zamierzona jako stan ostateczny" "71.

Ostateczna, to znaczy eschatyczna finalność przeznaczenia winna jednak być zapoczątkowana w egzystencji historycznej i ziemskiej. W takim właśnie sensie historycznym oraz społecznym i kulturowym przybiera wówczas postać realizacji konkretnych zadań życiowych. Realizacja ta określana jest mianem ,powołania"72.

Prawda teologiczna o człowieku stworzonym i odkupionym, ujawniającym siebie w czynie, który ma znamię wieczności i współtworzy przeznaczenie osoby ludzkiej, ta prawda jest, w swej najgłębszej treści, prawdą o wyjątkowej wielkości człowieka, którą tradycja myśli

70 Cfr. S. Rosik, Wezwanie do ludzkiej petni, [w:] S. Rosik, Wezwania i wybory moralne, Refleksje teologicznomoralne, Lublin 1992, 6466.

71 Ibidem, 67. Cfr. STh III q.1 a.8 ad pb.; q.3 a.1.

72 Na temat powołania jako implikacji przeznaczenia Cfr. S. Rosik, op. cit., 6879. 
preaching of a solution to the human problem, which is contained in the same text: „But the one and only Son, who is Himself God and is at the Father's side, has made Him known" (Jn 1:18). Christ as the icon of the Father makes it possible to understand the mystery of both God and man (cf. „Whoever sees me sees the Father" [Jn 14:9]). For this to be possible, ,we have seen", two other events were necessary: Verbum caro and Deus homo. „The Word of God is the God's Word for God. The Word of God Incarnated is the God's Word about the God for people. It is the showcase window of God among people. The Word of God becomes a window on God for man by the fact that man is able to look at it and see God in it. The word of God becomes a window on God also because there man can see why God is so anxious to put Himself to his eyes. [...]

For the showcase of God for God is God Himself-it speaks of the way in which God exists. By acting, God reveals who He is! A person reveals himself in his act. Zaœ actus personae is personae actus!"'62.

The answer to the question of Cur Deus homo? is the deepest answer to the question of who God is to man and at the same time an equally profound explanation of the question - who is man? (because of the depth of the answer to the question: who is man for God?). In such a light it is worth quoting the words of John Paul II:

„To Poland the Church brought Christ, the key to understanding that great and fundamental reality that is man. For man cannot be fully understood without Christ. Or rather, man is incapable of understanding himself fully without Christ. He cannot understand who he is, nor what his true dignity is, nor what his vocation is, nor what his final end is. He cannot understand any of this without Christ" $"$.

\footnotetext{
${ }^{62}$ Ibidem, 87.

${ }^{63}$ John Paul II. [Homily] on Victory Square. Warsaw 2.06.1979. In: Pilgrimage of John Paul II to Poland. Poznan - Warsaw 1979, 22.
} 
Zachodu nazywa godnością. Jest zarazem fundamentalnie ważnym dziedzictwem myśli św. Jana Pawła II.

\section{Podsumowanie}

W artykule autor przedstawia próbę zgłębienia istoty-człowieka, przechodząc za K. Wojtyłą, „od fenomenu do fundamentu”.

Człowiek jest ukazany (przypomniany), jako ten, który jest nie tylko przedmiotem norm, które regulują jego działanie moralne, lecz także jako ktoś, kto jest zdolny w swoim działaniu moralnym wyrazić siebie jako osobę.

Słowa kluczowe: człowiek, tajemnica, personalizm, Jan Paweł II

\section{Bibliografia}

Arystoteles, Zoologia. Historia Animalium, Warszawa 1982, 491, 911.

Bonora A., Człowiek obrazem Boga w Starym Testamencie, „Communio“ 2:1982 nr 2 (8), 13.

Buttiglione R., Myśl Karola Wojtyty, Lublin 1996.

Galarowicz J., Człowiek jest osoba. Podstawy antropologii filozoficznej Karola Wojtyly, Kraków 1994.

Gałkowski J.W., Wprowadzenie, RF 28:1980 z. 2.

Gogacz M., Wokót problemu osoby, Warszawa 1974.

Greniuk F., Idea naśladowania Chrystusa, [w:] Veritatis splendor. Przesłanie.

Jan Paweł II, Przekroczyć próg nadziei, Lublin 1994.

Mojek S., Maksymalizm moralny, [w:] Veritatis splendor. Przestanie moralne Kościoła, red. B. Jurczyk, Lublin 1994.

Pytel J.K., Człowiek obrazem Boga w Nowym Testamencie, „Communio” 2:1982 nr 2(8), 16-21.

Rosik S., Wezwanie do ludzkiej petni, [w:] S. Rosik, Wezwania i wybory moralne, Refleksje teologicznomoralne, Lublin 1992.

Seifert J., Blask prawdy jako fundament działania moralnego. O encyklice papieża Jana Pawta II ,Veritatis splendor”, w: Jan Paweł II, Veritatis splendor. Tekst i komentarze, Lublin 1995.

Siemieniewski A., Coraz bardziej jaśniejąc, upodabniamy się do Jego obrazu, [w:] W prawdzie ku wolności, Wrocław 1994.

Styczeń T., Bóg Ojcem. 
It is Christ who reveals the whole depth of the gift of man's election and vocation, but also reveals the burden of responsibility. This burden is placed on man by his own greatness, or more precisely by Creative Love with this gift of choice. Choosing, therefore, becomes a call (cf. amor meus pondus meum - "My weight is my love: by that I am carried, whithersoever I be carried.").

Accordingly, Christ, in whom God reveals his love, confirms that the essence of humanity, the very depth of the truth about man, is not so much freedom but love - a selfless, free, gratuitous and irrevocable gift of self.

„In a particular way, it is in the Crucified Christ that the Church finds the answer to the question troubling so many people today: how can obedience to universal and unchanging moral norms respect the uniqueness and individuality of the person, and not represent a threat to his freedom and dignity? (...) The Crucified Christ reveals the authentic meaning of freedom; he lives it fully in the total gift of himself and calls his disciples to share in his freedom. ${ }^{64}$

In Christ, especially in His Paschal Mystery, the very centre of the truth about man as an image of God, and also the inseparable truth about the new creation, is revealed. It can therefore be seen synthetically that the Christian, in the perspective of the primacy of freedom in an anthropological vision, complemented by the theological theme of the "new creation in Christ", owes the fact of being a ,new creature" to the fact that he is called to a supernatural communion with the Father by his Son in the Holy Spirit. That „new creation" is accomplished by participating in the paschal mystery of Christ, and the Christian, shaped to the image of Christ our Supreme Priest, lives to give glory to God, or rather to „be the glory of God”.

${ }^{64}$ Cf. Mojek, S. (1994) Maksymalizm moralny, [in:] Veritatis splendor. Przestanie moralne Kościoła, ed. Jurczyk, B. Lublin, 124-126. 
Styczeń T., Miłość a sens życia. Nad encyklika Jana Pawła II „Redemptor hominis”, [w:] Jan Paweł II.,Redemptor hominis. Tekst i komentarze, Lublin 1982.

Wojtyła K., Osoba i czyn, Kraków 1969.

Wojtyła K., Osoba: podmiot i wspólnota, RF 24:1976 z. 2.

Wojtyła K., Rozważania o istocie człowieka, Kraków 1999.

Wojtyła K., U podstaw odnowy, Kraków 1988. 
The recognition of anthropology focused not on freedom, but on love, finally makes it possible to see that the Christian has a divine filiality in the image of Christ through the Holy Spirit, and that he is liberated from sin and death. The „New Creature” also expresses existence in its dimension of a new community of life - the disciple of Jesus is a member of the new People of God (the Church), and is directed towards the ultimate fullness in Christ. ${ }^{65}$

The personal character of man, his rationality and possibilities resulting from his free will, the power of transcendence, the possibility of setting (recognizing) a goal and achieving it all definitely distinguish man from other creatures. It also imposes an obligation to form one's own life attitudes, corresponding to one's personal potential. It is also a sign of maturity, since a mature man reflects on the meaning of his own life, on the purpose of his efforts and intentions. For a religious man, the sphere of this goal and its authorship remain in a close and direct relationship with God. The words of St. Paul then become clear: „For those God foreknew, He also predestined to be conformed to the image of His Son (...) And those He predestined, he also called; those he called, He also justified; those He justified, He also glorified" (Rom 8:29 30).

Holy Bible, the Church's Tradition and the modern teaching of the Magisterium, including the encyclical Veritatis splendor, leave no doubt that the end of human destiny is God Himself and personal communion with Him.

„God put us in the world to know, to love, and to serve him, and so to come to paradise. Beatitude makes us « partakers of the divine nature » (2 Peter 1:4) and of eternal life [cf. Jn 17:3] With beatitude, man enters into the glory of Chris [cf. Rom 8:18] and into the joy of the Trinitarian life" $"$.

${ }^{65}$ Cf. VS 86-87.

${ }^{66}$ CCC 1721. 
The nature of many of the biblical statements is so clear that they bear witness.

The biblical vocabulary, followed by the terminology of other testimonies, simply defines the reality of lasting communion with God in terms of ,seeing”. (Cf. 1 Cor 13, 12; 1 J 3, 2; Rev 7, 9 16; $22,4)$. However, the Revelation clearly shows that man's destiny to see God directly belongs to the supernatural sphere, that is, to the level to which God alone can bring man up. Thus the content of destiny is, in the strict sense of the word, supernatural. ${ }^{67}$

The objective finalism of human life in the form of lasting communion with God does not exhaust the mystery of fate. After all, there remains the subjective aspect of subjectivity. It is primarily love for God and participation in His love. This means that Christian existence is directed towards love, which is the most important value. Furthermore, in this encounter of human love with God, who is Love, the total exaltation of human existence is achieved. This does not mean destroying the natural structure of a person's existence, but giving a completely new relationship to reality.

„Having reached the end of his destiny, man becomes the owner of what his whole being demands. All worldly desires are removed from him, and his participation becomes personal fullness, peace and inner silence. Such resting in God, giving birth to joy and a state of full saturation, is defined as salvific happiness (beatitudo) using the term of St. Thomas. Revelation shows that in God's plans it is intended as the final state." 68

The ultimate, that is to say, the eschatological finality of destiny must, however, be initiated in historical and earthly existence. In this historical, social and cultural sense, it then takes the form of the realisation of specific life tasks. This realisation is called a ,vocation'. ${ }^{69}$

${ }^{67}$ Cf. Rosik, S. (1992) Wezwanie do ludzkiej petni, [in:] S. Rosik, Wezwania $i$ wybory moralne, Refleksje teologicznomoralne, Lublin, 6466.

${ }^{68}$ Ibidem, 67. Cf. STh III q.1 a.8 ad pb.; q.3 a.1.

69 On vocation as the implications of destiny Cf. Rosik, S. op. cit., 6879. 
The theological truth about a man created and redeemed, who reveals himself in acting, who has the mark of eternity and contributes to the destiny of the human person, this truth is, at its deepest, a truth about the exceptional greatness of man, which the tradition of Western thought calls dignity. At the same time, it is a fundamentally important legacy of John Paul II's thought.

\section{Summary}

In the study, the author presents an attempt to explore the human being by following „from phenomenon to foundation” after K. Wojtyla.

Man is shown (reminded) as one who is not only the subject of norms that regulate his moral action, but also as someone who is able to express himself as a person in his moral acting.

Key words: man, mystery, personalism, John Paul II 